\title{
THE FEDERAL URBAN RENEWAL PROGRAM
}

\author{
QUINTIN JOHNSTONE*
}

7 HE FEDERAL government has exerted during the past twenty-five years great influence on the development and character of urban land use. The source of this influence has been primarily in terms of financial aid: loans, grants, mortgage insurance, and mortgage guarantees. ${ }^{1}$ The federal urban renewal program which includes planning and regulation of private land use as well as financial aid is the latest governmental effort directed at stopping the downward spiral of urban deterioration. ${ }^{2}$ This article will survey the program

* Associate Professor of Law, Yale Law School.

1 As of June, 1957, the Federal Housing Administration had insured mortgages on 5.2 million dwelling units, and insurance had totaled 35 billion dollars. This includes insurance on new and existing housing, but does not include property improvement loans of which 20 million have been insured by the Federal Housing Administration and have totaled 10 billion dollars of insurance. FHA, Monthly Report of Operations 4 (June, 1957). As of June, 1956, the United States Veterans Administration had guaranteed or insured 4.5 million mortgage loans on which the guarantees and insurance totaled 19.6 billion dollars. Administrator of Veterans Affairs, Annual Report 265 (1956).

2 In this article these terms are used with the following meanings: Blight includes slums, and deteriorated and deteriorating areas which may be vacant or which may have a predominate use that is residential, commercial, or industrial.

Redevelopment is the revision or replacement of an existing land use and population distribution pattern through the acquisition of a predominantly built-up area, and the clearance and rebuilding of this area according to a comprehensive plan.

Rehabilitation is the improvement or restoration of a predominantly built-up area according to a comprehensive plan. It may involve the reduction of population densities; the acquisition and clearance of scattered deteriorated buildings; the acquisition and improvement of deteriorated buildings; the repair, modernization, and provision of sanitary facilities; the provision of street, park, or other public improvements; or cleanup and maintenance work by property owners.

Conservation is the preservation of predominantly built-up areas that are in good condition. These are areas which are substantially in keeping with land use and population density requirements of a comprehensive plan, but which require continuing code enforcement, and may require public improvements to insure continued private investment therein.

Reclamation is the reassembly and replanning of relatively vacant and unimproved urban land tracts, often prematurely subdivided, which without such action cannot be put to proper use with proper population densities because of tax delinquency, clouded titles, substandard subdivision design, or topographic characteristics.

Urban renewal is redevelopment, rehabilitation, conservation, reclamation, or a combination of these, by government action or with government assistance.

Low-income families are those with gross incomes under $\$ 4,000$ in high cost areas and under $\$ 3,000$ in lower cost areas; middle-income families are those with gross incomes between $\$ 4,000$ and $\$ 8,000$ in high cost areas, and between $\$ 3,000$ and $\$ 6,000$ in lower cost areas.

The meanings given to redevelopment, rehabilitation, and conservation are substantially those of Chapin. Chapin, Urban Land Use Planning $231 \mathrm{n} .11$ (1957). Also see the definitions in Jacobs and Levine, Redevelopment: Making Misused and Disused Land Available and Usable, 8 Hastings L.J. 241, 245 (1957); and for the meaning of the terms urban redevelopment and urban renewal see Rhyne, Municipal Law 520 (1957). 
in terms of the factors leading to its adoption, its operational requirements, its present workability, and suggestions for a stronger and more effective program.

\section{The Problem of Urban Blight}

All large and most middle-sized American cities have extensive areas of blight with immediate prospects of these areas spreading. Blight is not restricted to residential neighborhoods but includes commercial and industrial areas as well. It is usually located in central cities, but some suburban communities have blighted areas and the amount of suburban blight will probably increase rapidly. The problem is most acute in the great industrial cities of the East and Midwest and in southern cities with large Negro populations.

Statistical data on the amount of blight is very limited and unsatisfactory. This is due to the difficulty of defining blight, difficulties in quantitatively measuring it, and the insufficient statistical survey work that has been done on the subject. More progress has been made in measuring residential blight than that of a commercial or industrial character. Blight is usually defined in terms of substandard buildings, an area being blighted if it has a high percentage of such buildings. ${ }^{3}$ Detailed indices of construction, plumbing facilities, maintenance,

${ }^{3}$ On the nature and measurement of blight see Chapin, Urban Land Use Planning 230-41 (1957); Dewhurst and Associates, America's Needs and Resources 218-20, 490-91 (1955); Twichell, Measuring the Quality of Housing in Planning for Urban Redevelopment, in Urban Redevelopment: Problems and Practices, Pt. 1 (Woodbury ed., 1953); and Walker, Urban Blight and Slums, c. 4 (1938).

HHFA characterizes blight in these terms for purposes of urban renewal: "For ease of reference the general term 'blight' is used in lieu of the terms 'slum, deteriorated or deteriorating' used in the Federal law.

"The HHFA does not undertake to establish specific criteria of blight to which project areas must conform. What is required is that the Local Public Agency support a determination based on any combination of the factors set forth below or on other factors which it feels render the area inadequate for decent living....

"It should be noted that criteria of residential blight fall into two principal categories: Those which are in themselves characteristics of residential inadequacy or unfitness and those which are not themselves characteristics but which have been found to be symptoms of blight. In developing its case the Local Public Agency should place primary emphasis upon the first category and use the latter as supporting material. The following is a list of commonly recognized factors of residential blight broken down into these two categories.

"Characteristics of residential blight: (1) Dilapidation or deterioration of structures and dwelling units. (2) Substandard alterations to structures and dwelling units. (3) Inadequate original construction of structures or dwelling facilities. (4) Inadequate dwelling facilities. (5) Obsolete dwelling facilities. (6) Improper building locations, coverage, and use of the land. (7) Inadequate or unsatisfactory community facilities.

'Symptoms of residential blight: (1) Economic deterioration; such as declining property value, high incidence of tax delinquency, or low average rents. (2) Existence of social problems-high incidence of delinquency, crime, etc. (3) Overoccupancy of dwelling units. (4) Premises improperly maintained.

"The following is a list of commonly recognized factors of non-residential deterioration broken down into these two categories.

"Characteristics of non-residential blight: (1) Dilapidation and deterioration of structures. (2) Inadequate original construction. (3) Inadequate basic building utilities and facilities.

(4) Obsolete or obsolescent building types. (5) Improper building location, coverage, and use 
sanitary conditions, overcrowding and amount of rent have been developed to measure substandardness of residential buildings. Other tests used to define and measure residential blight, of which the American Public Health Association's appraisal method is the best known, ${ }^{4}$ consider not only building deficiencies, but neighborhood deficiencies, including high population and building density, extensive non-residential land use, inadequate educational and recreational facilities, dangerous traffic, and unsanitary conditions. Blighted areas may also consist of such vacant land parcels as dead subdivisions and vacant lots in rundown communities. ${ }^{5}$ Some observers have added as a characteristic of blight that the area is stagnate or deteriorating instead of improving, ${ }^{6}$ others that the urban depreciation and renewal cycle is in an abnormally severe decline. ${ }^{7}$ Still another characteristic of blighted areas is that they are economic liabilities to local government for they almost always produce less in tax revenue than the cost of the public services they receive, such as police and fire protection and welfare assistance. ${ }^{8}$

of land. (6) Inadequate or unsatisfactory public facilities or utilities. (7) Adverse influences from noise, smoke, and fumes.

"Symptoms of non-residential blight: (1) Economic deterioration, such as growing tax delinquency or migration of firms from the area. (2) Premises improperly maintained." HHFA, Slum Clearance and Redevelopment Program, Manual of Policies and Requirements for Local Public Agencies, Pt. 2, c. 4, $\$ 2$ pp. 3-5. This manual is hereafter referred to as HHF A Local Public Agency MIanual.

The most detailed criteria for measuring commercial and industrial blight have been developed by a recently completed St. Louis study. City Plan Commission, St. Louis, Missouri, Measuring Deterioration in Commercial and Industrial Areas (1957) (mimeo.). Schedules were prepared of relevant characteristics for measuring the extent to which individual parcels have deteriorated, and weighted penalty points assigned to each characteristic so that a total score is attained showing the over-all degree of deterioration. Areas with a high percentage of highpenalty score structures can be classified as blighted. The characteristics listed in the measurement schedules are included under such headings as building conditions, code violations, site features, type of occupancy, and quality of the entire block on which the parcel is located. The St. Louis study was financed by the Urban Renewal Administration under its demonstration grant program.

1 Amer. Pub. Health Assoc., Standards for Healthful Housing: Planning the Neighborhood (1948), Planning the Home for Occupancy (1950), Construction and Equipment of the Home (1951).

On I feans of defining and measuring blight also see HHFA, How to Make and Use Local Housing Surveys (1954); and Darling, A Short-cut Method for Evaluating Housing Quality, 25 Land Economics 184 (1949).

${ }^{5}$ On blighted undeveloped land see Jones, Local Government Organization in Metropolitan Areas: Its Relation to Urban Redevelopment, in The Future of Cities and Urban Redevelopment 514-17 (Woodbury ed., 1953).

' Twichell, op. cit. supra note 3 , at p. 11 .

7 Colean, Renewing Our Cities 6-8 (1953).

${ }^{8}$ As a definition of blight this concept has been criticized, although admittedly an indication of the existence of blight. Twichell, op. cit. supra note 3, at pp. 12-14. On cost-revenue studies to determine whether or not an area is an economic liability see Chapin, op. cit. supra note 3, at pp. 241-50 (1957). 
Little quantitative data exist on the volume of commercial and industrial blight, but sufficient work has been done so that rough estimates can be made of the amount of residential blight. The most common source for estimating the total national'volume of residential blight and substandard housing is the 1950 United States Census of Housing. A widely quoted estimate has been made from these census results that 15 million substandard dwelling units existed in the United States in 1950. Substandard dwelling units are all those that the census classifies as dilapidated, lacking essential plumbing (running water, private toilet or bath), or located in substandard blocks-those in which over half of the dwelling units are dilapidated or lack essential plumbing. Nine of the 15 million substandard units were located in urban areas and amounted to 27 per cent of all urban dwelling units. Five and a half million were in substandard urban blocks, and are an important measure of the extent of urban neighborhood blight. ${ }^{9}$ In addition to the Census housing data for individual cities, other surveys of the amount of local urban blight have recently been made in some cities. ${ }^{10}$

A related problem is that of ascertaining areas that are particularly vulnerable to blight. As blight tends to flow gradually outward, these areas, sometimes called conservation areas, ${ }^{11}$ are likely to adjoin presently blighted neighborhoods -areas along major traffic arteries; those near central business districts; and those in which old structures predominate. The speed with which blight moves into a vulnerable area is most often a function of its proximity to existing blighted areas and the rate of increase in the city's low-income population.

Urban blight is caused by a great variety of forces. ${ }^{12}$ The most fundamental of these operating on American cities in modern times are increasing population, high population mobility, increasing urbanization including vast expansion of urban land use into peripheral land areas, a continuing high proportion of families with low incomes, racial segregation intensified by a great influx of racial minorities into central cities, and a fragmented system of governmental units that has been unable to effectively deal with area-wide urban problems. A less important cause is land speculation, including present holdings of slum prop-

${ }^{9}$ Census standards of dilapidation and essential plumbing are elaborated in 1 U.S. Census of Housing, Pt. 1, pp. xviii, xix (1950). For discussion of census statistics on housing conditions and blight see id., at xxii, xxiii; Dewhurst and Associates, America's Needs and Resources 221-22 (1955); and Wheaton, A Preliminary Estimate of Housing Needs, 1955-1970, The National Housing Conference, The Housing Yearbook 5 (1954).

${ }^{10}$ Brief indications of some of these survey results appear in Digest of Replies to Questionnaire, President's Advisory Committee on Government Housing Policies and Programs, Report 240-42 (1953).

1 See note 2 supra for a definition of conservation.

12 The causes of blight are discussed in Abrams, The Future of Housing 20-22 (1946); Ford, Slums and Housing, c. 19 (1936); Nelson and Aschman, Real Estate and City Planning, c. 34 (1957); and Walker, Urban Blight and Slums, c. 3 (1938). Statistical trends in population and housing are set out in FHHFA, Housing in the United States, a Graphic Presentation (1956). 
erties for anticipated high use sale, and speculation of the kind that led to the dead subdivisions of the thirties..$^{13}$ Other minor causes are the high cost of private assembly of large central city land tracts, the relatively high cost of constructing land improvements, and changes in housing fashions and maintenance cost that have made many large single-family dwelling units constructed a generation or more ago obsolete for anything but high density substandard occupancy. Also, the apparent downward trend in the proportion of family income spent for housing, as greater preference has developed for other kinds of consumer goods and services, ${ }^{14}$ may have increased the number of families willing to live in substandard housing. The operation of all these forces has led to more immediate causes of blight such as high density occupancy by low income families, depreciation of buildings and neighborhoods, the decrease in easy accessibility of central business districts, and the creation of new major traffic arteries.

\section{Governatent Efforts to Control Urban Blight}

The federal urban renewal program is the latest in a variety of government efforts that have been directed at least partially toward preventing and eliminating urban blight. Most of these efforts have been developed, financed and administered by local government. The present blighted character of American cities is evidence of the failure of government efforts to solve the blight problem, although without these efforts the problem would undoubtedly be far more severe.

Government blight prevention and elimination efforts have been of three kinds: planning, regulation of private land use, and financial aid. Prior to the federal urban renewal program, all large cities and many smaller ones were making blight control efforts, with emphasis being given to building and housing codes and zoning regulations. Many programs of government action combine more than one of these kinds of efforts; urban renewal combines all three. Urban planning efforts vary considerably but usually involve, among other things, surveys to identify blighted areas and plans for their rehabilitation. ${ }^{15}$ The principal forms of local government land use regulation that have been used to reduce and prevent blight are zoning, housing and building codes, and subdivision regulations. Urban zoning limits permissible private land use to residen-

${ }^{13}$ On dead subdivisions see The Future of Cities and Urban Redevelopment 514 (Woodbury ed., 1953); Nelson and Aschman, Real Estate and City Planning 288 (1957).

14 The weakening of consumer preferences for housing is discussed in Grebler, Blank and Winnick, Capital Formation in Residential Real Estate, c. 8 (1956); Guttentag, Winnick's Case for a Changing Attitude Toward Housing, 70 Q.J. Econ. 314 (1956); and Winnick, Reply, 70 Q.J. Econ. 319 (1956).

is On urban planning generally consult Chapin, Urban Land Use Planning (1957); Horack and Nolan, Land Use Controls, c. 2 (1955); McDougal and Haber, Property Wealth and Land, Pt. III (1948); Nelson and Aschman, Real Estate and City Planning (1957); Segoe, Lacal Planning Administration (1941); Walker, The Planning Function in Urban Government (1950); and Symposium, Urban Housing and Planning, 20 Law \& Contemp. Prob. 351 (1955). 
tial, commercial, or industrial uses and often to subclasses of these; and it commonly restricts the intensity of use by limiting height, bulk, and area coverage of buildings. ${ }^{16}$ Housing and building codes control construction, maintenance and occupancy ${ }^{17}$ of buildings, and may consist in part of health, fire, electrical, and plumbing ordinances. ${ }^{18}$ Subdivision regulations control the platting of what are ordinarily undeveloped tracts, and the form of street and utility installations on these tracts. ${ }^{19}$ The number, size and shape of lots is determined at the time of platting. Many cities have little or no vacant land available for subdividing, but statutes in some states authorize cities to regulate subdivision activity in nearby unincorporated areas. ${ }^{20}$

In addition to financial support for planning and regulatory efforts to control blight, local and state governments have extended other financial blight control aid. New and expanded government owned public works and institutions are occasionally built or operated for such a purpose. These may include schools, parks, playgrounds, streets, parking facilities, public transportation, and transportation terminals. Decent low-income housing of a permanent character tends to prevent blight. In New York, many state and local government low-income public housing projects have been built and are being operated without federal aid; ${ }^{21}$ and local public agencies in almost every state are participating in the federally assisted low-rent housing program involving some local subsidy. ${ }^{22}$

${ }^{16}$ On zoning consult Beuscher, Land Use Controls, Cases and Materials, c. 8 (1956); Horack and Nolan, Land Use Controls, cc. 2, 3 (1955); Metzenbaum, The Law of Zoning (2d ed., 1955); and Symposium, Land Planning in a Democracy, 20 Law \& Contemp. Prob. 197 (1955).

17 Occupancy restrictions involve such matters as density (number of residents per room or dwelling unit), minimum size of sleeping rooms, and business activities permitted on the premises.

${ }^{18}$ On housing and building codes consult, HHFA, Urban Renewal Bulletin No. 3, Provisions of Housing Codes in Various American Cities (1956); Guandolo, Housing Codes in Urban Renewal, 25 Geo. Wash. L. Rev. 1 (1956); Municipal Housing Codes, 69 Harv. L. Rev. 1115 (1956); and note 210 infra.

${ }^{19}$ On subdivision regulations consult Lautner, Subdivision Regulations (1941); McMichael, Real Estate Subdivisions (1949); HHFF, Suggested Land Subdivision Regulations (1952); and An Analysis of Subdivision Control Legislation, 28 Ind. L.J. 544 (1953). On the planning and development of subdivisions by private interests see Urban Iand Institute, The Community Builders Handbook (1956), which considers both public and private regulation.

${ }^{20}$ E.g., Minn. Stat. Ann. $\$ 462.26$ (1946); Texas Rev. Civ. Stat. Ann. Art. 974a, § 3 (Vernon, Supp., 1956).

21 The New York programs are discussed in New York State Division of Housing, 1956 Report. State and municipal public housing subsidies are authorized by N.Y. Public Housing Law $\$ \S 73,94$ (McKinney, 1955). Without approval of the commissioner, state subsidized public housing projects in New York cannot receive federal aid. Id., at $\$ 75$ (McKinney, Supp., 1957). Chicago has eight projects, containing 1,423 units, financed with state and city funds and without federal aid. Chicago Housing Authority Quarterly Report to the City Council (June 30, 1957). On state public housing aid also consult Colean, American Housing 273-75 (1944); and Riesenfeld and Eastlund, Public Aid to Housing and Land Redevelopment, 34 Minn. L. Rev. 610, 644-45 (1950).

${ }^{22}$ On federally aided low-income public housing see infra, p. 310 et seq. 
Beginning in 1941, state statutes began to be passed authorizing urban redevelopment by private enterprise. ${ }^{23}$ The purpose of the legislation was to eliminate slums and replace them with new housing, including housing for lowincome families. Inducements to private enterprise participation were cheaper and easier land assembly by authorizing the use of eminent domain $;^{24}$ and property tax exemptions. ${ }^{25}$ In some instances, eminent domain powers were vested in private redevelopers; in others, government agencies were authorized to use these powers to assemble tracts for private use. ${ }^{26}$ Redevelopment normally had to follow a government approved plan, and government regulation of rents and profits was required by some of the statutes. ${ }^{27}$ The existence of these statutes showing state and local willingness to proceed with clearance and redevelopment projects, and their general lack of success in securing private enterprise participation with the limited inducements afforded, helped influence Congress to adopt the federal urban renewal program in $1949 .{ }^{28}$ Some of the state acts apparently were passed in anticipation that a federal assistance program was forthcoming; and after enactment of the Federal Housing Act of 1949, more state acts were passed to enable the localities to take advantage of the federal program.

Local government resources, initiative and effective power to control blight are seriously limited. American cities, without extensive financial aid from the federal government or the states, are generally unable to carry out major redevelopment or low-rent housing programs that involve heavy government subsidy. Central cities, where blight is concentrated, are especially hardpressed. Their need for expanded local government services is increasing rapidly

23 These statutes are discussed in Brown, Urban Redevelopment, 29 B. U. I. Rev. 318 (1949); Riesenfeld and Eastlund, Public Aid to Housing and Land Redevelopment, 34 Minn. L. Rev. 610, 626-28 (1950); Hill, Recent Slum Clearance and Urban Redevelopment Laws, 9 Wash. \& Lee L. Rev. 173 (1952); and "Conservation"-A New Area for Urban Redevelopment, 21 U. of Chi. L. Rev. 489 (1954).

24 E.g., Ill. Stat. Ann. c. 671., $\$ \S 259(8), 292$ (Supp., 1956), eminent domain power granted private redevelopers; Mich. Stat. Ann. $\$ 5.3058(17)$ (1949), eminent domain by cities for benefit of private redevelopers.

${ }^{25}$ E.g., Mass. Ann. Laws c. 121A, $\$ 10$ (1957), forty years property tax exemption granted urban redevelopment corporations.

${ }^{26}$ Note 23 supra.

${ }^{27}$ E.g., N.Y. Unconsol. Laws $\$ \S 3408,3415$ (1949).

28 "States and cities are increasingly aware of the social costs of slums, of the threat to municipal solvency arising from the spread of slums and from the increasing spread of new building to the outskirts of cities, and of the heavy municipal outlays for city services in slum areas, which greatly exceed the tax revenues derived from those areas. Nevertheless, they have lacked the financial resources to undertake more than a few scattered slum-clearance projects under the redevelopment legislation which is now on the statute books of half of the states."

"On the basis of these facts, and the findings of previous congressional investigations during the past five years, it seems clearly established that only through an effective program of Federal aid can real progress be made in the clearance of slums." Report of the Seaate Committee on Banking and Currency, Sen. 1070 (Housing Act of 1949), 81st Cong. 1st Sess. 11 (1949). 
at a time when blight and decentralization are lowering tax base values and draining off sources of tax income. With a few exceptions, state governments cannot or will not make sizeable subsidies available to alleviate urban blight.29 One important factor operating against state-aid is that the legislatures of many states that have blight-ridden cities are controlled by rural elements antagonistic to increasing state expenditures for relief of city problems. ${ }^{30}$ Nor has local government shown a capacity to deal with area-wide metropolitan problems. Effective action of this sort is usually prevented by the pattern of urban government: many independent suburbs clustered around a large central city, and the entire area commonly overlapping county and state lines. When the interests of these government units conflict, and on local urban development and renewal methods and who shall pay for them they usually do, collective action is almost impossible. Some trend toward more effective metropolitan area government seems to be developing, but so far it has had little impact.

Local government blight control through regulation has also been of limited effectiveness. ${ }^{31}$ Building and housing codes, zoning regulations, and subdivision regulations are often poorly drafted, antiquated, and unenforced; in smaller cities they may be non-existent. These codes and regulations commonly disclose lack of adequate planning, as well as favoritism to those politically well-connected. The critical shortage of low-income housing has been a major deterrent to enforcement of building and housing codes, especially density restrictions, because enforced codes would decrease the amount of such housing. Zoning as a blight preventive device has been weakened in many ways: by too many variances, exceptions and spot-zoned parcels; too much property zoned exclusively for single-family dwellings; permitting residential and commercial uses in areas zoned industrial; lack of coordinated plans for zoning metropolitan areas; and frequent failure to zone unincorporated rural-urban fringe areas. Judicial refusal to support some kinds of zoning ordinances has been a deterrent to blight control, even though the decisions may be justified on other grounds. ${ }^{32}$ Subdivision

${ }^{29}$ E.g., in New York the state has given substantial aid to public housing, authorized by N.Y. Pub. Housing Law $\$ 73$ (McKinney, 1955); state aid has been made available for urban redevelopment, authorized by $\mathrm{Pa}$. Stat. Ann. Title 35, $\$ 1664$ (Purdon, Supp., 1956); and Minnesota has recently authorized state aid for redevelopment projects. Minn. L. (1957) c. $810, \$ 7$.

${ }^{30}$ For a militant discussion of this problem from the cities' point of view see Mattison, American Cities' Struggle Under Unfriendly State Governments, 17 Nimlo Munic. I. Rev. 211 (1954). On unbalanced political representation of urban areas see Baker, Rural Versus Urban Political Power (1957).

31 On the weaknesses of local government blight control through regulation see the findings of Siegel and Brooks, Slum Prevention Through Conservation and Rehabilitation 1-3 (1953), a nine-city study of conservation and rehabilitation made for the President's Advisory Committee on Government Housing Policies and Programs.

${ }^{32}$ E.g., West Palm Beach v. State ex rel. Duffey, 158 Fla. 863, 30 So. 2d 491 (1947) (ordinance to create aesthetic building uniformity held invalid as having no lawful purpose); Ronda Realty Corp. v. Lawton, 414 Ill. 313,111 N.E. $2 d 310$ (1953) (requirement that apart- 
regulation has also had limitations. It has too often been ineffectual to prevent ultimate blight because unrelated to plans for development of the rest of the metropolitan area; and many kinds of tracts have been widely exempted from regulation, such as those in unincorporated areas and those involving less than five lots. ${ }^{33}$

The federal government has carried on two major programs designed to prevent urban blight: low-income housing and urban renewal. In addition, other federal programs and policies have had significant impacts on blight. For example, the federal public assistance grant-in-aid program, by providing funds to millions of indigent persons, has enabled most welfare recipients to live in housing that meets fairly satisfactory standards of health and decency. Without this program, the volume of seriously substandard housing would probably be much greater than it is. Federal policies on population mobility have also had an effect on urban blight. Immigration restrictions since the mid-twenties have almost entirely shut-off the flow of new low-income residents from other countries that earlier contributed so much to the growth of urban wealth but also to urban slums. The effect on urban blight of immigration restrictions has been countered by the policy of free population mobility within the United States, including Puerto Rico, that has enabled great numbers of low-income persons to move from rural areas and small towns to the cities-and their slums-in response to urbanization pressures. An opportunity to prevent urban blight from developing in the future has been ignored by FHA, the Veterans Administration, and the Home Loan Bank Board in their financial aid programs that have given such a great stimulus to post-war housing construction, especially in outlying urban areas. The lack of local and metropolitan planning requirements in these aid programs has made most areas of new urban housing far more vulnerable to blight. ${ }^{34}$ The vastly accelerated federal highway assistance program provided for by the Federal-Aid Highway Act of $1956^{35}$ threatens to similarly increase

ment houses have garage space held to violate equal protection); Reschle v. Winnetka, 363 Ill. 478, 2 N.E. 2 d 718 (1936) (residential zoning near a commercial area held unconstitutional as a violation of due process); Vernon Park Realty, Inc. v. Mount Vernon, 307 N.Y. 493, 121 N.E. 2d 517 (1954) (restricting property to parking purposes violates due process); and Akron v. Chapman, 160 Ohio St. 382, 116 N.E. 2d 697 (1953) (due process violated if zoning ordinance applies retroactively to a non-conforming use).

${ }^{33}$ E.g., Wis. Stat. Ann. \$ 236.02(7) (West, 1957); Cal. Bus. and Prof. Code Ann. § 11535 (Supp., 1957).

34 "[T]he Home Loan Bank Board, the Federal Housing Administration and the Veterans Administration have done less than nothing to encourage better neighborhoods. They have supported the largest single class, single price, single-dwelling-type neighborhoods in national history, done nothing significant to develop or enforce standards of neighborhood open space, aided and abetted a completely chaotic development of suburban areas, and largely ignored areas already developed or partly developed." Wheaton, The Evolution of Federal Housing Programs 467 (unpublished Ph.D. dissertation in University of Chicago Library, 1953).

3570 Stat. 374 (1956), 23 U.S.C.A. \$ 151 et seq. (Supp., 1957).

On the new federal highway program consult Netzer, Financial Policy for Highways: Impact of the 1956 Federal Legislation, 10 National Tax J. 114 (1957). Urban transportation 
urban blight. Without coordinated planning, the new highways and expressways constructed over the next 15 years pursuant to this act will needlessly cause many contiguous urban areas to deteriorate and will hamper efforts at redevelopment. Although some efforts have been made to coordinate the highway aid program with government blight control efforts, ${ }^{36}$ there are disturbing signs of interagency frictions. ${ }^{37}$

Substantial federal efforts directed at eliminating blight began in 1933 with passage of the National Industry Recovery Act. This act instituted the federal public housing program, ${ }^{38}$ and its purposes were not only to eliminate slums and improve low-income housing, but to increase employment and help bring the economy out of the depression. ${ }^{39}$ Until 1937 the program was carried out by the Housing Division of the Public Works Administration, a federal agency which bult and operated public housing without state or local participation. By 1937, PWA had completed or contracted for 21,000 dwelling units. Most of these units have since been transferred to local government ownership and operation. ${ }^{40}$ A major shift in federal public housing policy took place with passage of the United States Housing Act of 1937. 11 This Act established the present system of federal loans and grants-in-aid to local public housing authorities. The shift was influenced partly by judicial decisions holding that the federal government could not use the power of eminent domain to take land for slum clearance and public housing purposes. ${ }^{42}$ The federal public housing program under the United States Housing Act of 1937 was originally administered by the United States Housing Authority, an agency of the Department of the Interior, but, since 1947, has been administered by the Public Housing Administration, which has

problems and their relation to urban growth and decay are discussed in Owen, The Metropolitan Transportation Problem (1956); Urban Land Institute, Technical Bulletin 31, The New Highways: Challenge to the Metropolitan Region (1957).

${ }^{36}$ E.g. Coordination with Major Highway Programs, HHFA, Local Public Agency Letter No. 103 (September 12, 1957).

${ }^{37}$ Urban Renewal and Urban Highways, National Association of Housing and Redevelopment Officials, 9 Newsletter No. 17, at 1 (September 15, 1957).

3848 Stat. 201 (1933). A chronology of all federal actions affecting housing from 1898 to 1949 appears in U.S. Senate Banking and Currency Committee, Federal Housing Programs (committee print, 1950). On the evolution of the federal public housing program, also see Abrams, The Future of Housing, cc. 19-21 (1946); Colean, American Housing 276-82 (1944); Robinson and Weinstein, The Federal Government and Housing, [1952] Wis. L. Rev. 581; and Wheaton, The Evolution of Federal Housing Programs (unpublished Ph.D. dissertation in University of Chicago Library, 1953).

${ }^{39} 48$ Stat. 195 (1933).

10 By the end of 1955, all but fourteen of the forty-eight PWA-built projects had been transferred to local housing authorities. PHA, Ninth Annual Report 8 (1955).

4I 50 Stat. 888 (1937), as amended, 42 U.S.C.A. $\$ 1401$ et seq. (Supp., 1957).

42 United States v. Certain Iands in the City of Louisville, 78 F. 2d 684 (C.A. 6th, 1935); United States v. Certain Lands in the City of Detroit, 12 F.Supp. 345 (E.D. Mich., 1935). These cases are discussed in Ebenstein, The Law of Public Housing, c. 3 (1940). 
also administered federal emergency housing programs. ${ }^{43}$ To some extent, Congress has integrated the public housing program with urban renewal.44

The other major federal effort designed to prevent and eliminate slums, the federal urban renewal program, came into being with passage of the Housing Act of $1949 . .^{45}$ This act also set forth a national policy on housing, greatly expanded the federal public housing program, and initiated a construction and repair program for farm dwellings. The 1949 Act was the culmination of five years of effort by proponents of a broad federal housing program to secure a comprehensive bill. The controversial Wagner-Ellender-Taft Bill, ${ }^{46}$ that contained urban redevelopment provisions, passed the Senate in 1946 but was not passed by the House and subsequent efforts to secure comprehensive federal housing legislation failed until 1949. Each year since 1949, except 1950 and 1951, Congress has passed housing legislation amending or adding urban renewal provisions. ${ }^{47}$ The most important changes in urban renewal were made by the Housing Act of 1954, and involved a change in urban renewal philosophy. The Housing Act of 1954 is based on the premise that the government attack on slums and blight would be more effective if more emphasis were placed on prevention and rehabilitation. It broadened the urban renewal program by adding a workable program requirement, Sections 220 and 221 mortgage insurance, urban planning assistance grants, and demonstration grants; and it broadened the definition of an urban renewal project to include rehabilitation and conservation in addition to slum clearance and redevelopment. The primary objective was still to be slum elimination and improvement of housing. ${ }^{48}$ The Housing Act of 1954 fol-

${ }^{13} \mathrm{By}$ the end of 1955, the Public Housing Administration had almost completed the liquidation of approximately one million emergency dwelling units, most of them built to house World War II civilians and servicemen. PHA, Ninth Annual Report 18 (1955).

1 See p. 315 et seq infra.

463 Stat. 413 (1949), 42 U.S.C.A. $\$ 1441$ et seq. (1952).

${ }^{15}$ Sen. 5192, 79th Cong. 1st Sess. (1945). The redevelopment program provided for in this bill is similar to that of the Housing Act of 1949.

Congressional housing developments during the period 1945-49 are discussed in Colean, The Impact of Government on Real Estate Finance in the United States, c. 8 (1950). For a discussion of the interest groups that favored and opposed the Wagner-Ellender-Taft Bill and the tactics they used, see Wheaton, The Evolution of Federal Housing Programs, c. 16 (unpublished Ph.D. dissertation in University of Chicago Library, 1953).

4766 Stat. 98 (1952), 67 Stat. 121 (1953), 68 Stat. 590 (1954), 69 Stat. 635 (1955), 70 Stat. 1091 (1956), 71 Stat. 294 (1957), 42 U.S.C.A. § 1441 et seq. (Supp., 1957).

18 " In so broadening the provisions of the existing slum clearance and redevelopment law, your committee is not changing in any way the primary and principal objective of this law; namely, the improvement of the housing condition of American families. Its primary and principal objective continues to be the elimination of slums and other inadequate housing and an increase in supply of good housing. Rehabilitation and conservation-type projects must, therefore, be evaluated against this basic test. If such a project clearly results in a general upgrading and improvement of the dwelling accommodations in the area, then Federal financial assistance (by permitting their inclusion as local grants-in-aid) for the installation or reconstruction of streets, playgrounds, and other public facilities needed for the improvement of the neighborhood environment contributes directly to the accomplishment of the primary objec- 
lowed in large part recommendations made by a presidential advisory committee of housing specialists, heavily weighted with officers of private lending institutions. ${ }^{49}$

Federal urban renewal is a grant-in-aid program requiring the participation of local public agencies. Before these agencies can take part in the federal program, state law or its equivalent for areas without statehood, must authorize them to do so. Forty-two states, the District of Columbia, Alaska, Hawaii, Puerto Rico and the Virgin Islands have enabling legislation or constitutional provisions authorizing participation in the program; and most of the legislation has been tested in litigation and upheld as constitutional..$^{50}$ States that have not passed enabling legislation are Idaho, Mississippi, Montana, New Mexico, Utah, and Wyoming. ${ }^{51}$ Enabling acts in Florida, Georgia, Kansas, and South Carolina

tive and is fully justified as an essential part of the Federal aid authorized for the improvement of housing conditions. If such a project does not clearly result in a general upgrading and improvement of the dwelling accommodations in the area, then such Federal financial assistance for streets, playgrounds, and other public facilities amounts to Federal aid for local public works. The latter result is not intended." Report of the Senate Committee on Banking and Currency on Sen. 1472 (Housing Act of 1954), 83d Cong. 2d Sess. 35 (1954).

49 "A piecemeal attack on slums simply will not work-occasional thrusts at slum pockets in one section of a city will only push slums to other sections unless an effective program exists for attacking the entire problem of urban decay. Programs for slum prevention, for rehabilitation of existing houses and neighborhoods, and for demolition of wornout structures and areas must advance along a broad unified front to accomplish the renewal of our towns and cities. This approach must be vigorously carried out in the localities themselves, and will require local solutions which vary widely from city to city.

"The Committee is impressed with the tremendous interest evident throughout the country in rehabilitation and neighborhood conservation as well as the important corrective efforts recently launched in some of the cities. The program recommended here is designed to encourage and stimulate this activity. . . ."President's Advisory Committee on Government Housing Policies and Programs, Report 1 (1953). For Committee's membership see id., at 376.

${ }^{50}$ State urban renewal enabling legislation, constitutional provisions and judicial decisions appear in URA, Citations to Basic Enabling Legislation and Selected Cases on Urban Redevelopment and Urban Renewal (as of September 1, 1956), reprinted in part in Guandolo, Housing Codes in Urban Renewal, 25 Geo. Wash. L. Rev. 1, 50 (1956) (App. A). Cases are collected in Validity, Construction and Effect of Statutes Providing for Urban Redevelopment by Private Enterprise, 44 A.L.R. 2d 1414, 1417 (1955).

In 1957, urban renewal enabling legislation was for the first time adopted in Iowa, Iowa Sen. 184, Reg. Sess. (1957); Nevada, Nev. L. (1957) c. 335; Texas, Tex. L. (1957) c. 298; Vermont, Vt. H.R. 369, Reg. Sess. (1957); and Washington, Wash. L. (1957) c. 213. Many other states modified their urban renewal legislation during 195\%, the usual purpose being to provide for rehabilitation and conservation. For citations to urban renewal legislation passed from October 15, 1956 to June 15, 1957, see HHFA, Office of General Counsel, Office of the Administrator, Report No. 3 on State Legislation (1957).

Leading cases upholding the constitutionality of enabling legislation include Berman v. Parker, 348 U.S. 26 (1954), People ex rel. Gutknecht v. Chicago, 3 IIl.2d 539, 121 N.E.2d 791 (1954); Kaskel v. Impellitteri, 306 N.Y. 73, 115 N.E.2d 659 (1953), cert. denied 347 U.S. 934 (1954); and Belovsky v. Redevelopment Authority, 357 Pa. 329, 54 A.2d 277 (1947).

${ }^{51}$ In 1954 Louisiana repealed basic portions of its urban renewal enabling act: La. L. (1954) Act 709, repealing La. Rev. Stat. $\$ \$ 40: 481$ B, C; and La. L. (1954) Act 711, repealing La. Rev. Stat. $\$ \S 40: 474(13),(14)$. Since this repeal, URA classifies Iouisiana as not having adequate urban renewal legislation. URA, Citations to Basic Enabling Legislation and Selected Cases on Urban Redevelopment and Urban Renewal (as of September 1, 1956) 6. 
have been held unconstitutional, ${ }^{32}$ but in Georgia and Kansas, new enabling legislation has been passed, ${ }^{53}$ and there are urban renewal projects underway in both states. ${ }^{54}$

HHFA refuses to extend financial aid to localities until adequate state enabling legislation exists, and in some instances it has withheld aid until the constitutionality of such legislation has been judicially tested. Model enabling legislation has been prepared by HHFA's Division of Law for use by interested states, ${ }^{55}$ and upon request, the agency will review proposed enabling legislation to determine whether it provides the necessary authority to local public agencies..$^{56}$

The strong legislative support that the federal urban renewal program has received is due to its broad political appeal and the small amount of organized interest group opposition to it. The program's most influential support with legislatures has probably come from the mayors of American cities. They have fought hard for urban renewal, having found that dramatic slum clearance and redevelopment projects are popular with municipal voters, enable municipal property taxes to be increased, and make possible the financing of major public improvements. ${ }^{57}$ Influential support has also come from large private builders, mortgage bankers, local chambers of commerce, labor unions, and large real property owners whose holdings are near urban renewal areas. Property owners who have been especially vigorous in promoting the program are universities, churches, and large retail stores in the path of blight movements who find it difficult or impossible to relocate. Commercial retail interests also often anticipate more and better customers from nearby redevelopment projects. Vigorous advocacy of federal participation in the program has come from the federal agency most concerned, the Housing and Home Finance Agency. Less politically

${ }^{52}$ Adams v. Housing Authority, 60 So.2d 663 (Fla. 1952); Housing Authority v. Johnson, 209 Ga. 560, 74 S.E.2d 891 (1953); State ex rel. Fatzer v. Redevelopment Authority, 176 Kan. 145, 269 P.2d 484 (1954); Redevelopment Authority v. State Corporation Comm., 171 Kan. 581, 236 P.2d 782 (1951); and Edens v. Columbia, 228 S.C. 563, 91 S.E.2d 280 (1956).

${ }^{53} \mathrm{Ga}$. Code Ann. $\$ \$ 69-1101$ to $1119,99-1201$ a to $1214 \mathrm{a}$ (Supp., 1955), passed after an amendment to the Georgia Constitution authorized slum clearance and redevelopment legislation, Ga. Const., Art. XVI (1954); Kan. Gen. Stat. Ann. §§ 17-4742 to 4761 (Supp., 1955), upheld as constitutional in State ex rel. Fatzer v. Kansas City, 179 Kan. 435, 296 P.2d 656 (1956).

54 HHFA, Urban Renewal Project Directory (June 30, 1957).

${ }^{55}$ See HHFA, Slum Clearance and Urban Renewal Bill for States Without Any Slum Clearance and Redevelopment Laws (October 12, 1956); and HHFA Model Urban Renewal Bill for States Which Have Redevelopment Laws Patterned After a Model Bill (October 12, 1956).

${ }^{56}$ HHFA, Local Public Agency Manual, Pt. 1, c. 3, \$ 1. (1955). What HHFA considers the necessary local public agency legal powers for loan and grant assistance under the federal urban renewal program is set out id., at $\$ 3$.

${ }^{57}$ See testimony and statements of mayors representing their cities, the United States Conference of Mayors, and the American MIunicipal Association. Hearings before Subcommittee of the Senate Committee on Banking and Currency on Housing Amendments of 1957, 85th Cong. 1st Sess. (1957) 579-654, 911-30. 
powerful, but vocal and intelligent, has been the backing of citizens' and professional organizations, notably the National Association of Housing and Redevelopment Officials, the National Housing Conference, and the American Council to Improve Our Neighborhoods.

Since passage of the Federal Housing Act of 1949, opposition to federal urban renewal has come mostly from two sources: locally from the occupants and owners of property in clearance areas, and nationally from the economy bloc in Congress and the administration desirous of reducing the federal budget and restricting the functions of the federal government. Business occupants that must relocate have been better organized and effective in their opposition than have displaced residents; and their hostility has not been directed at urban renewal as such, but at the sites selected for redevelopment. The administration opposition is centered in the Treasury Department, Bureau of the Budget, and Council of Economic Advisors, ${ }^{58}$ and has shown itself in efforts to reduce federal urban renewal expenditures and in sponsorship of the Joint Federal-State Action Committee of Governors and Federal Officials which is studying ways of shifting to the states entire responsibility for some federal grant-in-aid programs that may include urban renewal. ${ }^{59}$

The de-emphasis that the urban renewal program has given to new federally aided public housing has helped broaden the program's support with business interests. Even though unsubsidized private enterprise cannot provide decent low-income housing, realtors, building and loan associations, mortgage bankers, and the residential building industry have carried on intense lobbying activities against public housing. ${ }^{60}$ These business interests are opposed to any present or prospective reduction in their business opportunities by government financed

\footnotetext{
58 Particularly strong opposition was exerted by the Eisenhower Administration to reduce the authorized urban renewal expenditures in the 1957 housing bill to 175 million dollars. Congress approved 350 million dollars, which is indicative of the program's political appeal; but HHFA plans to commit only 250 million dollars of this amount during fiscal 1958 unless "it appears that this amount is insufficient to maintain vigorous progress in urban renewal." Statement by HHFA Administrator Cole, National Assn. of Housing and Redev. Officials, Newsletter (Aug. 15, 1957) 1. Administration opposition to further large urban renewal authorization by Congress will probably be renewed during 1958. The administration attitude toward urban renewal is discussed in 1957 Housing Act, $14 \mathrm{~J}$. of Housing 230 (1957).

${ }^{59}$ In a preliminary report, the Joint Federal-State Action Committee has recommended that the states assume fiscal responsibility for planning advances in connection with urban renewal projects, and proposed to give future additional consideration to urban renewal. Report of the Joint Federal-State Action Committee to the President of the United States and to the Chairman of the Governors' Conference, Progress Report No. 1, pp. 10, 13 (1957). For a strong statement against shifting to the states responsibility for current federal grant-in-aid programs see 2 Labor's Economic Review (AFL-CIO), No. 10 (1957).

${ }^{60} \mathrm{On}$ lobbying of real estate and building interests against public housing, see Hearings before House Select Committee on Lobbying Activities on H.R. 298 (Pt. 2), 81st Cong. 2d Sess. (1950). Lobbying activity by trade unions, citizens' groups, and government agencies was also inquired into at these hearings. For the particular organizations that have been active in opposing public housing see Wheaton, The Evolution of Federal Housing Programs, c. 16 (unpublished Ph.D. dissertation in University of Chicago Library, 1953).
} 
and operated housing, irrespective of social need. They apparently are fearful that if the volume of public housing is allowed to increase, it will eventually become competitive with unsubsidized private housing. Considerable business group support has existed for subsidizing low-income families through a rent certificate device, and for restricting public housing by low income maximums for occupants, requiring local referenda as a condition to establishing local projects, prohibitions on promotion of public housing by federal agencies, and disposal of projects by sale to private interests.

\section{ORGANIZATION OF GOVERNAIENT FOR URBAN RENEWAL}

Congress has authorized the Administrator of the Housing and Home Finance Agency to carry out the major features of the federal government's functions under the urban renewal program. ${ }^{61}$ The administrator has delegated the bulk of these functions to the Urban Renewal Administration, under the general supervision of a commissioner. ${ }^{62}$ The Housing and Home Finance Agency was established in $1947,{ }^{63}$ and has responsibility for most federal housing programs. The Urban Renewal Administration is one of five subordinate units and agencies under the control of the Housing and Home Finance Agency ${ }^{64}$ The others are the Federal Housing Administration, the Public Housing Administration, the Federal National Mortgage Association, and the Community Facilities Administration. ${ }^{65}$ URA does not perform all federal urban renewal functions. FHA insures Sections 220 and 221 mortgages, $\mathrm{PHA}$ is responsible for administering federal participation in the low-rent public housing program, and the HHFA Administrator has some non-delegable urban renewal duties. ${ }^{66}$ Most direct relations of local public agencies with the federal government on urban renewal are with the urban renewal personnel of HHFA field offices: regional offices in New York, Philadelphia, Atlanta, Chicago, Forth Worth, and San Francisco, and an area office in Puerto Rico ${ }^{67}$ A Board of Review in the Washington office of URA

6163 Stat. 414 (1949), as amended, 42 U.S.C.A. $\$ \S 1451,1456$ (Supp., 1957). The legal responsibilities of the Administrator are described in 21 Fed. Reg. 10186-7 (1956).

62 HHFA Administrator's Reorganization Order No. 1, 19 Fed. Reg. 9303 (1954). Prior to creation of the Urban Renewal Administration, most urban renewal functions were performed by an HHFA division, the Division of Slum Clearance and Urban Renewal.

e3 Reorganization Plan No. 3 of 1947, 61 Stat. 954 (1947), 5 U.S.C.A. § 133y-16 (1950).

64 For a general description of HHFA and its constituent agencies and units see 21 Fed. Reg. 10187-9 (1956); HHFA, Annual Reports; and U.S. Government Organization Manual 429 $(1956-57)$.

${ }^{65}$ In the balance of this article, these common abbreviations will be used: HHFA, Housing and Home Finance Agency; URA, Urban Renewal Administration; FHA, Federal Housing Administration; PHA, Public Housing Administration; and FNMA, The Federal National Mortgage Association.

${ }^{66}$ The HHFA Administrator's non-delegable duties are set out in 68 Stat. 623 (1954), 42 U.S.C.A. \$1451(c) (1957).

${ }^{67}$ The organization of HHFA regional and area offices is described in HHFA, Local Public Agency Manual Pt. 1, c. 2, § 2 (1955). 
reviews regional and area office recommendations on urban renewal. HHFA and its subordinate units and agencies employ about 11,000 persons. ${ }^{68}$

In addition to the usual type of operating branches, the URA has a racial relations officer assigned to racial relations problems and two public advisory committees appointed by the HHFA Administrator: the Urban Renewal Advisory Committee and the Demonstration Grant Program Advisory Committee. ${ }^{69}$ The coordination of federal housing policy has been facilitated by formal organizations within the federal government created for this purpose. A National Housing Council has been established to coordinate housing policy among federal agencies and departments, ${ }^{70}$ HHFA has an Advisory Board for Agency Policy Coordination to coordinate policy among the constituent units and agencies of HHFA, ${ }^{71}$ and HHFA has a Congressional Liaison Officer to aid in its dealings with Congress. These offices and bodies have little effective power or significance.

Local government functions under the federal urban renewal program are carried out by what the federal statutes refer to as local public agencies. These may be "any state, county, municipality or other government entity or public body" authorized to undertake urban renewal projects. ${ }^{72}$ Nearly all of the local public agencies are cities, housing authorities, or redevelopment agencies whose jurisdictions are city-wide only. ${ }^{73}$ In some cities, more than one local government or government department has authority to participate in the urban renewal program, and this has led to inter-agency power struggles in New York City and elsewhere. Enabling legislation generally requires affirmative action by the governing body of a city before its local public agency can start to act under the federal program. ${ }^{74}$ HHFA recommends that each local public agency establish a citizens advisory committee. ${ }^{75}$ These are usually city-wide organizations,

${ }_{68}$ The estimated total number of HHFA employees for urban renewal and all other functions is 10,986. The Budget of the United States for the Fiscal Year ending June 30, 1958, App. 87-93. The Office of the Administrator, including URA and the regional offices, employed 1,711; FNMA, 786; FHA, 6301; and PEA, 2188. Ibid.

${ }^{69}$ The formal organization of URA is described in HHFA, Local Public Agency Manual Pt. 1, c. 2, §1 (1955).

7021 Fed. Reg. 10185 (1956).

${ }^{71} 19$ Fed. Reg. 9303 (1954), as amended 20 Fed. Reg. 6031 (1955).

7263 Stat. 421, 42 U.S.C.A. $\$ 1460$ (h) (1957).

${ }^{73}$ Examples of enabling acts providing for various types of local public agencies are $\mathrm{II}$. Rev. Stat. (1955) c. $67 \frac{1}{2}, \S 27$ (housing authorities), $\$ 73$ (land clearance commissions), $\$ 91.11$ (conservation boards); N.Y. Gen. Munic. Law, \$72m (McKinney, Supp., 1957) (municipalities); Pa. Stat. Ann. Tit. 35, $\$ 1709$ (Purdon, 1949) (redevelopment authorities). 1949).

${ }^{74}$ E.g., Ill. Rev. Stat. (1955) c. $67 \frac{1}{2} \S 91.11$; Pa. Stat. Ann. Tit. 35, $\$ 1704,1705$ (Purdon,

75 "This division cannot emphasize too strongly the desirability of an advisory committee for every locality that is undertaking a Title I program. Through such a device the local public agency will be able to mobilize resources not otherwise available and gain increased effectiveness in performing its functions. Among other benefits it will receive invaluable aid in the most 
but in Chicago some success has been achieved with neighborhood conservation and renewal organizations. ${ }^{78}$ Congressional control and influence over the urban renewal program is of course very great. In addition to frequent statutory modifications of the program and annual appropriations for it, congressional power is exerted in other ways. For example, members of the House and Senate commonly exert pressure on HHFA to secure approval for projects in cities within their districts; and the HHFA administrator, FHA commissioner, and PHA commissioner are appointed by the President by and with the advice and consent of the Senate. ${ }^{77}$ Lack of control by the HHFA administrator over appointments of FHA and PHA commissioners is one reason why FHA and PHA have not been better integrated into the urban renewal program.

\section{Forar and Amount of Federal Urban Renewal AfD}

Urban renewal is primarily a grant-in-aid program under which grants and loans are made to local public agencies under restrictive conditions imposed by the federal government. The physical work of renewal is done by local public agencies and participating private business. The federal government maintains many other grant-in-aid programs for which it allocates funds to state and local governments. ${ }^{78}$ During 1956 , these grants-in-aid totaled $\$ 3,230,000,000 .{ }^{79} \mathrm{In}$ addition to urban renewal and public housing, the largest federal grants-in-aid are for public welfare assistance, ${ }^{80}$ highway construction, ${ }^{81}$ employment security, ${ }^{82}$ removal of surplus agricultural commodities, ${ }^{83}$ and the national school

important aspects of the slum clearance and urban redevelopment program-such as the widest possible understanding of it, the collective judgment of the community on how it can best be conducted, and widespread public support in carrying out the projects." HHFA, Advisory Committees, Local Public Agency Letter No. 24 (September 29, 1953).

76 Generalizations from the Chicago experience appear in Brussat, Citizens Organization for Neighborhood Conservation, Nat'l. Ass'n. of Housing and Redevelopment Officials, Special Publication No. 12 (1957). Brussat concludes that to be successful, full-time professional staff and support of major interest groups in the neighborhood are needed; and that slumdwellers can seldom be effectively organized.

77 Reorganization Plan No. 3 of 1947, 61 Stat. 954 (1947), 5 U.S.C.A. § 133y-16 (1950).

${ }^{78}$ On federal grants-in-aid see Anderson, The Nation and the States, Rivals or Partners, c. 11 (1955); Council of State Governments, Federal Grants-in-Aid (1949); Governmental Affairs Institute, The Impact of Federal Grants-in-Aid on the Structure and Functions of State and Local Governments (1955) (submitted to the Commission on Intergovernmental Relations); U.S. Commission on Intergovernmental Relations, Report to the President (1955); U.S. Commission on Intergovernmental Relations, Twenty-five Federal Grant-in-Aid Programs (1955).

${ }^{73}$ U.S. Secretary of the Treasury, Annual Report 565 (1956).

${ }^{80}$ In 1956, aid for public assistance, including old age assistance, aid to dependent children, aid to the blind, and aid to permanently and totally disabled amounted to $\$ 1,450,000,000$. Id., at 563 .

81 Amounting to $\$ 728,000,000$ in 1956 . Id., at 561 .
${ }^{82}$ Amounting to $\$ 226,000,000$ in 1956 . Id., at 564 .
83 Amounting to $\$ 144,000,000$ in 1956 . Id., at 561 . 
lunch program. ${ }^{84}$ Most federal grants-in-aid are to the states rather than local government, most are conditioned on the recipient government matching part or all of the federal grant, and many contain extensive non-financial conditions to further federal purposes and increase the likelihood of efficient administration. Recipients have the option of rejecting federal grant-in-aid opportunities, but the financial benefits are so great that generally this is not done. Grants-inaid by states to local government are also a common phenomenon in modern American government. ${ }^{85}$

Except for administrative guidance and minor planning and research assistance, federal urban renewal aid has been entirely financial. This financial aid is provided for all phases of the program: grants and loans for redevelopment projects, urban planning assistance grants, demonstration grants, mortgage insurance and public housing.

Grants and loans for redevelopment projects. Overwhelming emphasis in federal urban renewal has been placed on this phase of the program. Redevelopment projects, as the term is used here, are those projects under the federal urban renewal program that involve land acquisition and improvement with the aid of federal loans or capital grants. They are authorized by Title $I$ of the Housing Act of 1949 , as amended ${ }^{86}$ and are sometimes referred to as Title I urban renewal projects. Although under Title I they may involve improvements of vacant or open tracts of land or the rehabilitation of existing buildings, nearly all have involved substantial or total clearance of built-up tracts and construction of new buildings on them. ${ }^{87}$ From 1949 to 1957 , Congress authorized urban renewal project capital grant expenditures of $1 \frac{1}{4}$ billion dollars, with 100 million more authorized if the president determines that this increase is in the public interest. ${ }^{88}$ As of June 30,1957 , about 895 million dollars in capital grant funds had been committed by the federal government to specified redevelopment projects, commitments consisting of disbursements, grant contracts and reservations. ${ }^{89}$ Only 900 million dollars in redevelopment project grant funds had been authorized on that date, for the Housing Act of $1957^{\circ}$ that authorized 350 million dollars more in such funds did not become effective until July 12, 1957.

84 Amounting to $\$ 81,000,000$ in 1956 , plus $\$ 50,000,000$ for a school milk program. Id., at 561 .

85 On state financial aid to local government consult Ford, State and Local Finance, 226 The Annals 15 (1949).

${ }^{86} 63$ Stat. 414 (1949), as amended, 42 U.S.C.A. $\S \S 1450-60$ (Supp., 1957).

${ }^{87}$ Redevelopment projects may include not only redevelopment but also rehabilitation and reclamation as those terms are defined in note 2 supra.

8863 Stat. 416 (1949), as amended, 42 U.S.C.A. $\$ 1453$ (b) (1957). This entire sum is available for redevelopment projects, except that up to five million dollars of it may be used for demonstration grants. 68 Stat. 629 (1954), 42 U.S.C.A. \$ 1452(a) (1957).

${ }^{89}$ HHFFA, Urban Renewal Project Directory, June 30, 1957; HHFA, Report of Urban Renewal Operations, Table 1 (June 30, 1957).

90 71 Stat. 294 (1957). 
Despite considerable urging by interest groups, the president has not released the 100 million dollars in capital grant funds that he controls. Capital grants are gifts in the sense that they are not to be repaid; loans must be repaid and bear interest. Congress has authorized the HHFA administrator to obtain up to 1 billion dollars in funds for federal redevelopment project loans. ${ }^{91}$ The loan fund is a revolving one and on June 30,1957 , federal urban renewal loans outstanding totaled 48.9 million dollars. ${ }^{92}$

As of June 30, 1957, 3 redevelopment projects under the federal urban renewal program were completed, and 432 more were approved by HHFA and under way in the planning or contract execution stage. ${ }^{93}$ These projects were in 268 cities, located in 32 states, the District of Columbia, Alaska, Hawaii and Puerto Rico. ${ }^{94}$ The states with enabling laws but without redevelopment projects on June 30, 1957, were Arizona, Iowa, Louisiana, Nevada, North Carolina, Oklahoma, South Dakota and Washington. ${ }^{95}$ Most large cities have more than one project, ${ }^{96}$ and slightly over half of the redevelopment grant funds are committed to projects in cities of over 500,000 population. ${ }^{77}$ Many projects involve federal capital grants of over one million dollars each, a few of over 20 million dollars each. ${ }^{98}$ Fifty-five projects are under way in Puerto Rico, which is more than in any state or territory. ${ }^{99}$ In acreage, the largest project area approved for final planning or execution is 474 acres, the smallest one acre, with most of them comprising 10 to 100 acres each. ${ }^{100}$ The 272 projects approved for final planning or execution as of June 30,1957, involved 10,304 acres containing un-

91 63 Stat. 415 (1949), 42 U.S.C.A. § 1452(e) (1957).

${ }^{92}$ As of June 30,1957 , federal planning advances outstanding totaled 10.1 million dollars, federal temporary loans outstanding totaled 38.8 million dollars, and non-federal temporary loans outstanding (secured by the pledge of rights under federal temporary project loan contracts) totaled 107.7 million dollars. HHFA, Report of Urban Renewal Operations, Table 3 (June 30, 1957).

${ }_{93}$ National Association of Housing and Redevelopment Officials, Newsletter 3 (August 15, 1957). Of the 435 projects approved as of June $30,1957,163$ were in preliminary planning, 91 in final planning and 181 in project execution. HHFA, Urban Renewal Project Characteristics 6 (June 30, 1957).

94 HHFA, Urban Renewal Project Directory (June 30, 1957).

${ }^{95}$ Ibid. and see note 50 supra.

${ }^{96}$ E.g., Chicago, 20; New York, 17; Philadelphia, 11; Detroit, 7; Atlanta, 3; Denver, 3; and Los Angeles, 2. HHFA, Urban Renewal Project Directory (June 30, 1957).

${ }^{97}$ HHFA, Urban Renewal Project Characteristics 7 (June 30, 1957).

${ }^{98}$ Projects with federal grant commitments in excess of 20 million dollars are the Northwest Project, Washington, D.C., 40 million dollars; Southwest Project, Area C, Washington, D.C., 24 million dollars; Hyde Park-Kenwood Project, Chicago, 26 million dollars; Lincoln Square, New York City, 25 million dollars; and Eastwick, Philadelphia, 22 million dollars. HHFA, Urban Renewal Project Directory (June 30, 1957).

${ }^{99}$ But the total federal capital grants committed to Puerto Rican projects total only 18 million dollars. Ibid.

${ }^{100}$ HHFA, Urban Renewal Project Characteristics 9 (June 30, 1957). 
der the old use 143,123 dwelling units and 124,029 families. ${ }^{101}$ All but 20 projects involve total clearance. ${ }^{102}$

The Federal Housing Act of 1949, as amended, authorizes federal capital grant payments to local public agencies to help pay the costs of redevelopment projects. ${ }^{103}$ When the land has been acquired by a local public agency and is ready for redevelopment, the usual plan requires its sale to private builders for construction of buildings and other improvements on it in accord with the redevelopment plan. The capital grant and matching local funds are used to make up the difference between the project costs to the local public agency and the amount that private redevelopers pay for the land. Sale proceeds have been averaging only about one-third of gross project costs. ${ }^{104}$ Land acquisition and disposition costs amount to about two-thirds of local public agency gross project costs; the remaining costs consist mostly of surveys and planning, relocation, site clearance and improvements, supporting facilities (such as streets and playgrounds), interest, and administrative costs. ${ }^{105} \mathrm{Much}$ of the writedown upon sale goes to pay for old buildings that have been bought and demolished before sale of the land. Even though 80 per cent of the dwelling units in old buildings on clearance projects are substandard, the buildings are of considerable value and must be paid for when title to them is taken from their owners. ${ }^{106}$

Incentives to private business interests buying redevelopment project land are the writedown subsidy; general improvement in the whole area caused by the redevelopment plan; and in some instances, favorable government mortgage insurance. Writedowns are often subsidies to redevelopers only in that they make the price of project land competitive with prices of non-project land located in other parts of the metropolitan area and available for the redevelopers' purposes. ${ }^{107}$ Another inducement to private redevelopment is that the tract as-

${ }^{101}$ Id., at 8 . Six of the 272 projects are not included in these computations.

${ }^{102}$ Approximately twenty out of 266 projects are known to include some area for which rehabilitation of existing structures was reported in a survey made as of December 31, 1956. These data are tentative. Letter from the Program Analysis Section, URA (1957).

10363 Stat. 416 (1949), 42 U.S.C.A. \$ 1453 (1957).

104 HHFA, Urban Renewal Projèct Characteristics 12 (June 30, 1957).

${ }^{105}$ Ibid. Project costs that may be paid for with federal capital grant funds are set out in HHFA, Local Public Agency Manual, Pt. 2, c. 10, \& 2 (1955).

${ }^{106}$ In 266 out of 272 projects approved for final planning or execution as of June 30,1957 , 115,391 of the 141,135 original dwelling units were substandard. HHFA, Urban Renewal Project Characteristics 8 (June 30, 1957).

107 This is recognized by HHFA. "The high cost of buying slum and blighted real estate has always been the major impediment limiting private investment in the rebuilding of decadent areas of cities. To overcome this obstacle, Title $I$ authorizes the payment to Local Public Agencies of capital grants to help such agencies absorb necessary losses incurred in bringing the price of the assembled and cleared land down to the point where it is feasible to redevelop the land in accordance with a redevelopment plan designed to meet the needs of the locality." HHFA, Local Public Agency Manual, Pt. 2, c. 8, § 1, p. 2 (1955). See Colean, Renewing Our Cities 135 (1953). 
sembly function has already been performed. Private assembly of the dozens of separately owned parcels ordinarily needed for a major building enterprise is often difficult and sometimes impossible. The local public agencies, with the aid of eminent domain powers, perform this function.

Restructions are placed by the Housing Act on the kind of areas that capital grants may be used for and the types of improvements that may be made in these areas. Redevelopment project grants can only be made for renewing areas that are slums, blighted, deteriorated, or deteriorating. ${ }^{108}$ They cannot be made for projects consisting of open land. ${ }^{109}$ Redevelopment project areas must be predominantly residential ${ }^{110}$ before or after renewal and HHFA considers any area predominantly residential if over one-half of it is residential in character..$^{111}$ The usual effect of redevelopment projects has been to clear out slums ${ }^{112}$ and replace them with upper-income housing or commercial or industrial structures. ${ }^{113}$ New uses of project areas for low-income housing have been extremely small ${ }^{14}$ even though the projects have displaced a large number of low-income families. This result can be supported at least in part because many of the project areas are not well suited to residential housing. Despite Congressional indications that improvement of housing is the primary objective of the urban renewal program, ${ }^{115}$ many important projects have as their primary purpose the revival of

10863 Stat. 414 (1949), as amended, 42 U.S.C.A. $\$ 1452$ (a) (1957); 68 Stat. 626, 42 U.S.C.A. $\S 1460$ (a), (c) (1957). For HHFA's characterization of "slums, blighted, deteriorated, or deteriorating," see note 3 supra. This restriction does not apply to disaster areas. 70 Stat. 1101 (1956), 42 U.S.C.A. $\$ 1462$ (1957). Nor need disaster area projects comply with workable program, general plan, public hearing or predominantly residential requirements applicable to other redevelopment projects. Ibid.

${ }^{109} 63$ Stat. 416 (1949), as amended, 42 U.S.C.A. $\$ 1453$ (a) (1957).

1063 Stat. 420 (1949), as amended, 42 U.S.C.A. $\$ 1460$ (c) (1957).

II The HHFA interpretation of "predominantly residential" is set out in HHFA, Local Public Agency Manual, Pt. 2, c. 4, §2, pp. 2, 3 (1955), and in Local Public Agency Letter No. 64 (Dec. 12, 1955). In application, HHFA has been liberal in determining what is predominantly residential, e.g., The Coliseum Site Dispute in New York City, 102 Arch. Forum 17 (May, 1955).

${ }^{112}$ In 266 out of 272 projects approved for final planning or execution as of June 30,1957 , the original character of the project areas in 239 instances was blighted residential, in 14 cases other kinds of blight, and in 13 cases the areas were open or predominantly open. HHFA, Urban Renewal Project Characteristics 8 (June 30, 1957).

us In 264 out of 272 project areas approved for final planning or execution as of June 30 , 1957 , the predominantly or exclusive new uses were private residential, 140; commercial, 48; industrial, 37; public residential, 11; other kinds of public use, 28. Secondary uses were private residential, 34; commercial, 140; industrial, 50; public residential, 13; and other kinds of public use, 100 . Id., at 10 . The new uses in acres are public rights of way, 2,765; residential, 4,078; commercial, 1,217; industrial, 1,341; and other kinds of public and semi-public non-residential use, 821 . Id., at 8 . Of the 85,836 new or proposed new housing units, 60,707 are private rental; 17,303 , private sales; and 7,826 public rental. Ibid. Apparently few if any of the new private rental or sales units can be afforded by low-income families, and few of them by middle-income ones.

u4 Ibid. $\quad$ 15s Note 48 supra. 
business districts that have been declining due to suburban or outlying business competition. Project area improvements to fulfill this purpose are new store and office buildings; hotels; markets; parking facilities; traffic patterns; and, adjacent to the business districts, new high income apartments to add retail sales volume. Fulfillment of this purpose has been facilitated by a qualification to the residential requirement for capital grants that allows up to 10 per cent of all authorized funds to be used for projects in which the areas are not predominantly residential before or after renewal. ${ }^{116}$ But for the 10 per cent exception to apply, the project area must contain a substantial amount of residential blight before renewal and the area must not be suited to predominantly residential use.

An important restriction on redevelopment project grants is that they may not be used for constructing or improving buildings. ${ }^{117}$ Buildings are expected to be financed primarily by private funds supplied by private redevelopers. For every dollar of federal capital grant funds expended on redevelopment projects, it is estimated that local government and private business will spend five dollars in redeveloping project areas. ${ }^{118}$ Funds for some building construction in project areas can be secured from other federal sources, including public housing loans and grants and public building or facility loans. 119

A federal capital grant for a redevelopment project can be made only if the local public agency matches the federal grant by paying at least one-third, or in some instances one-fourth, of the net project or writedown cost. ${ }^{120}$ Some local and state government non-cash contributions to the project area may constitute local grants-in-aid. ${ }^{21}$ These include certain land donations, demolition and removal work, supporting facilities, and site improvements. The question of what are non-cash grants-in-aid and how they are computed has been a focal point of disagreement between HHFA and the local public agencies. Examples of contributions that HHFA considers not properly included are donations of land in

14668 Stat. 627 (1954), as amended, 42 U.S.C.A. $\$ 1460$ (c) (1957). This section also qualifies the predominantly residential requirement for loans and advances by permitting them to be made to develop open land for non-residential uses. But these loans and advances may not exceed $2 \frac{1}{2}$ percent of the estimated gross project costs of all the other urban renewal or redevelopment projects undertaken by the agency involved. Ibid.

117 Ibid.

118 Address by Acting URA Commissioner Steiner, November 13, 1956.

${ }^{119} 63$ Stat. 414 (1949), as amended, 42 U.S.C.A. $\$ 1452$ (a) (1957).

12063 Stat. 416 (1949), as amended, 42 U.S.C.A. $\$ 1454$ (1957), as amended, 71 Stat. 294 (1957). Capital grant contracts entered into prior to the Housing Act of 1957 are all on a onethird basis. The Housing Act of 1957 provided an alternative means of computing the local grant-in-aid share. It can either be determined on the previous one-third basis, or a locality can contract to bear only one-fourth of the cost using a method of computation less favorable to the localities. The amendment apparently was in response to pressure by the localities to decrease their grant-in-aid share. Examples of this pressure are statements by the mayors of Philadelphia, Baltimore, and Chicago. Hearings before Subcommittee of the Senate Committee on Banking and Currency on Housing Amendments of 1957, 85th Cong. 1st Sess. 598, 634, 923 (1957).

12163 Stat. 420 (1949), as amended, 42 U.S.C.A. $\$ 1460$ (d) (1957). 
existing streets and alleys; low-rent public housing; schools or other facilities which will be under private ownership or control; repairs, maintenance and rehabilitation work which may improve but not change the basic nature or capacity of an improvement or facility; and survey and planning work. ${ }^{122}$ Slightly over half of local grant-in-aid is of a non-cash character. ${ }^{123}$ Some cities can finance their grant-in-aid share entirely from the higher tax base resulting from redevelopment. ${ }^{124}$ To encourage effective relocation of project area occupants, Congress has provided that relocation payments to displaced families and businesses may be made with federal funds but without any requirement of matching local grants-in-aid. ${ }^{125}$

Congress has restricted the amount of loan and capital grant funds that may be expended in any one state to $12 \frac{1}{2}$ per cent of the authorized total. ${ }^{126}$ But an exception has been provided that permits 100 million dollars in capital grants to be allocated free of this restriction. ${ }^{127}$ It has been claimed that this restriction is undesirable in that it will unduly impede renewal in the older and larger Eastern states whose blight problems are so severe, and that the benefit these states should receive would be equalized by their disproportionate contributions to soil conservation, dam construction and other federal programs for internal improvements in the less populous states. ${ }^{128}$ As of June 30,1957 , the states with the largest capital grant commitments were New York, Pennsylvania, and Illinois. ${ }^{129}$ In committing capital grant funds, HHFA does not withhold funds for cities that are tardy in applying. Commitments are made as soon as a locality qualifies, irrespective of what it or its state or region has already received, subject only to the statutory limitation on what any one state can receive.

Federal redevelopment project loans to local public agencies are primarily designed to finance the very costly renewal process until it advances far enough

${ }_{122}$ HHFA, Local Public Agency Manual, Pt. 2, c. 10, $\$ 4$ (1955).

123 HHFA, Urban Renewal Project Characteristics 12 (June 30, 1957).

124 President's Advisory Committee on Government Housing Policies and Programs Report 238-39 (1953).

12570 Stat. 1100 (1956), as amended, 42 U.S.C.A. $\$ 1456(\mathrm{f})(1)$ (1957).

12663 Stat. 419 (1949), as amended, 42 U.S.C.A. $\$ 1456$ (e) (1957). The Housing Act of 1957 raised it from ten percent. New York is probably the only state that will benefit from this increase.

127 For a local public agency to qualify for part of this 100 million dollars it must be in a state to which the federal government has already obligated two-thirds of that state's share of capital grant funds. Ibid.

128 Hearings before House Committee on Banking and Currency on H.R. 5827 (Fousing Amendments of 1955), 84th Cong. 1st Sess. 165 (1955).

${ }_{129}$ Capital grant commitments as of June 30, 1957, including disbursements and reservations, were 134 million dollars for New York, 83 million dollars for Illinois, and 82 million dollars for Pennsylvania. Of these amounts, 110 million dollars were for New York City, 76 million dollars for Chicago, and 43 million dollars for Philadelphia. HHFA, Urban Renewal Project Directory (June 30, 1957). 
for other funds to be available to the localities. ${ }^{130}$ Receipt of these funds is always delayed. A long delay takes place before land is sold for redevelopment and the proceeds obtained by the localities. The federal government disburses no capital grants to the localities until at least substantial progress on a project has been made, and some and possibly all of the payments may not be made until the local public agency has completed its work on the project. ${ }^{131}$ And the locality may be delayed in securing funds for its share of grants-in-aid. Most redevelopment project loans are short term, although they may extend for 40 years if used to finance areas that are leased for redevelopment rather than sold. ${ }^{132}$ URA encourages local public agencies to seek urban redevelopment financing from private lending sources to conserve federal loan funds. ${ }^{133}$

Urban planning assistance grants. Congress has established a separate grantin-aid program to encourage urban planning in areas where such planning is needed but where little has been done due to lack of personnel, funds, or incentive. ${ }^{134}$ This program for urban planning assistance grants was initiated by the Housing Act of 1954 and provides funds on a 50-50 matching basis for planning four varied types of urban areas: cities under 25,000 in population, metropolitan or regional areas, areas suffering major natural disasters, and areas threatened with rapid urbanization as the result of federal installations. Ten million dollars has been authorized as the federal share of the program. It is administered by URA and the HHFA regional offices. ${ }^{135}$

The planning work done under the urban planning assistance grants has varied considerably but frequently has included studies of community economic base and growth trends, preparation of workable program codes and plans, ${ }^{136}$ and the replanning of areas destroyed or damaged by disasters. As of June 30, 1957, 83 urban planning assistance contracts had been approved involving planning assistance for 424 small communities in 22 states and 30 metropolitan areas and urban regions in 16 states. ${ }^{137}$

${ }^{130} 63$ Stat. 414 (1949), as amended, 42 U.S.C.A. $§ 1452$ (a) (1957).

${ }_{131}$ Partial capital grant progress payments can be made at URA's option, but will be made only after at least 25 per cent of the real estate (based on estimated costs) for the project has been acquired. Payments prior to completion of the project will not be made in excess of 75 per cent of the estimated total capital grant for the project. HHFFA, Local Public Agency Manual, Pt. 4, c. $2, \S 6$ (1955).

13263 Stat. 414 (1949), as amended, 42 U.S.C.A. § 1452(a) (1957).

${ }^{133}$ HHFA, Local Public Agency Manual, Pt. 1, c. 4, § 1 (1955).

13468 Stat. 640 (1954), as amended, 40 U.S.C.A. $\S 461$ (Supp., 1957). This program is commonly referred to as the Section 701 program.

${ }^{35}$ Requirements and procedures are amplified in HHFA, A Guide to Urban Planning Assistance Grants (1955).

${ }^{136}$ For discussion of workable programs see p. 337 infra.

${ }^{137}$ Current Programs and Operations of the Housing and Home Finance Agency (July 29, 1957). A February 23, 1957, release showed 242 small communities and 23 metropolitan areas and urban regions participating at the end of 1956. 
Urban planning assistance grants for small cities can be made only to state planning agencies; $;^{138}$ and the metropolitan and regional area grants can be made only to state, metropolitan or regional planning agencies. These restrictions have resulted in the creation and expansion of many state and other largearea planning activities. Metropolitan planning agencies participating in the program include those in the Detroit, Atlanta, Little Rock, Savannah, Nashville, Denver and Cleveland areas. These efforts hold some promise of solving the problem of anarchy among local government units in metropolitan areas. A trend may be under way of implementing metropolitan plans by giving real power to a metropolitan super-government, or by all cities in the area adopting ordinances or entering into contracts consistent with the plan. ${ }^{139}$ Implementation of plans is most likely to start with single problems such as water, sewers and highways. Factors favorable to the gradual elimination of local government anarchy are rising tax rates in suburban towns that are reducing the value of their independence, the increasing water shortage that makes cooperation in use more essential, and the weakening of political machines in some central cities. Weighed against these factors is a class conflict. The suburbs, that are predominantly middle class, do not want to be engulfed by the power of the working classes that have such a big voice in central city decision making. Suburban independence can protect middle class values on such matters as schools, zoning, location of traffic arteries, and racial segregation. Also, there are still tax advantages in most suburban areas remaining independent; and their local public officials have a strong vested interest in this independence.

Demonstralion grants. The most important government sponsored research on urban renewal is that provided for by the demonstration grant program. ${ }^{140}$ This program was created by the Housing Act of 1954,141 and provides for a federal matching grant-in-aid to local and state public bodies for research on slum and blight elimination. The federal government bears two-thirds of the cost of this

\footnotetext{
${ }^{139}$ A somewhat similar grant-in-aid program was formerly provided by TVA to state planning commissions in Alabama and Tennessee. TVA Annual Report 20-21 (1941).

${ }^{139}$ On the government of metropolitan areas consult Jones, Local Government Organization in Metropolitan Areas: Its Relation to Redevelopment, in The Future of Cities and Urban Redevelopment, Pt. IV (Woodbury ed., 1953); and Symposium, Metropolitan Regionalism: Developing Governmental Concepts, 105 U. of Pa. L. Rev. 439-616 (1957).

${ }^{140}$ Some valuable research relevant to urban renewal, including guides to fulfilling workable program requirements, was prepared by the HHFA Division of Housing Research in 1954 and earlier. See notes 212,214 and 215 infra. Congress has vacillated in its attitude toward permitting HHFA to do research. Broad authorization was provided for in the Housing Acts of 1948 and 1949, 62 Stat. 1276 (1948), and 63 Stat. 431 (1949), 12 U.S.C.A. \$ 1701(f) (1952), but the program was liquidated effective April, 1954, 67 Stat. 305 (1953). On HHFA housing research see HHFA, Eighth Annual Report 7 (1954). Apparently the demonstration grant program was intended to partially fulfill research needs arising after liquidation of the earlier housing research program.
}

14168 Stat. 629 (1954), as amended, 42 U.S.C.A. $\$ 1452$ (a) (1957). This program is commonly referred to as the Section 314 program. 
work and the localities or states one-third, although in some cases private foundations are paying some of the localities' costs. Congress has authorized up to 5 million dollars as the total federal share of all projects under this program. The program is administered by URA. ${ }^{142}$ Only public bodies may contract with URA for demonstration grants, although the public bodies may subcontract with private universities and other research organizations for the work involved.

As of June 30,1957, 21 demonstration grant projects had been authorized, 1 of which was completed. ${ }^{143}$ Most of the others are scheduled for completion by or before early 1958. Most of the public bodies that have contracted for these grants are large cities, but the University of California has contracted for two and other state agencies for four. The matching fund requirement has restricted interest in the program. In accord with statutory directives, ${ }^{144}$ the projects deal with methods and techniques of blight prevention. Many of them should be of value as guides to other localities, and will preserve some of the best local solutions to urban renewal administrative problems which otherwise would be lost from view with the passage of time. Upon completion of each project, reports will be published and these will prove valuable additions to the literature on blight prevention. Among the most helpful should be the Philadelphia project on voluntary rehabilitation, the New York West Side project that explores renewal possibilities other than total clearance for a high-density residential area, a Chicago project on relocation, a St. Louis study on measuring commercial and industrial deterioration, and a University of California project on local government organization for urban renewal. ${ }^{145}$ The usual project is a case study of only one area.

Mortgage insurance in aid of urban renewal. When the Housing Act of 1954 was passed, a broadened program of mortgage insurance was heavily relied on by Congress to effectuate the act's philosophy that urban renewal requires rehabilitation and prevention as well as clearance and redevelopment. The act added two new sections, $220^{146}$ and $221,{ }^{147}$ administered by FHA, and designed specifically to further the ends of urban renewal by means of mortgage insurance on residential property. Mortgages on most all types of housing may be insured by these sections: single family and multi-family; sales and rental; new, existing

${ }_{142}$ The administration of the demonstration grant program and its procedures are described in HHFA, A Guide to Demonstration Grants (revised April, 1957).

${ }^{143}$ FHFA, Report of Urban Renewal Operations, Table 1 (June 30, 1957).

144 See note 141 supra.

${ }^{145}$ For a description of the scope of approved projects, see HHFA, A Report on Urban Renewal Demonstrations (Dec., 1956). The St. Louis study is described in note 3 supra.

14668 Stat. 596 (1954), as amended, 12 U.S.C.A. $\S 1715(\mathrm{k})(1957)$.

F7 68 Stat. 596 (1954), as amended, 12 U.S.C.A. $\$ 1715-1$ (1957). Sections 220 and 221, and the workable program section, 68 Stat. 623 (1954), as amended, 42 U.S.C.A. $\$ 1451$ (c) (1957), contain most of the mortgage insurance requirements mentioned in the text of this article. FHA regulations pertaining to Sections 220 and 221 insurance appear in 24 Code Fed. Regs. $\S \S 261-68$ (Supp., 1957), as amended, 22 Fed. Reg. 6290 (1957). 
and rehabilitated. The purpose of Section 220 is to assist in financing rehabilitation of existing dwellings and constructions of new dwellings in urban renewal areas; that of Section 221 to assist in financing relocation housing, and particularly the construction of new housing, ${ }^{148}$ for families displaced by urban renewal and related government activity. FHA insurance under these and other FHA programs encourages private lending by insuring the lender against loss on mortgage loans. It does not protect the borrower. Losses are paid in debentures following default, with FHA taking title to the mortgaged property and succeeding to the mortgagee's rights against the mortgagor. The mortgage financing that FHA will insure comes from private sources, but a limited federal program for purchasing at par Sections 220 and 221 mortgages held by lenders has been developed to further encourage the financing of urban renewal and relocation housing by assuring that a market exists for mortgages on such housing. The purchase program is restricted to mortgages on private residential property which cannot be marketed at an adequate price. FNMA, a constituent agency of HHFA, administers the mortgage purchase program..$^{149}$

To qualify for Section 220 insurance, the property involved must be located in an urban renewal project area, in a locality which has had a workable program approved by $\mathrm{HHFA},{ }^{150}$ and a redevelopment or urban renewal plan for the area must have been approved by HHFA. If the mortgagor is the owneroccupant, the insured mortgage may be for as much as 97 per cent of the value of the property. ${ }^{151}$ The maximum amount insurable for a single-family dwelling is $\$ 20,000$, with larger coverage provided for multiple-family dwellings. Maturities cannot exceed 30 years; nor interest exceed 5 per cent per year unless FHA raises the rate, which it may do up to 6 per cent, upon a finding that this is necessary to meet the mortgage market. ${ }^{152}$

148 FHA, Operations Letter No. 228, FHA Policy Considerations in the Administration of Section 221 (May 22, 1957).

${ }^{19}$ The FNMIA Section 220 and 221 mortgage purchase program is authorized by 68 Stat. 616 (1954), as amended, 12 U.S.C.A. $\$ 1720$ (1957), and is described in FNMA Special Assistance for Urban Renewal, HHFA, Local Public Agency Letter No. 72. As of March 28, 1957, 100 million dollars had been allocated for these purchases but only 22 million dollars had been spent or committed. Hearings before Subcommittee of the Senate Banking and Currency Committee on Housing Amendments of 1957, 85th Cong. 1st Sess. 123 (1957). On FNMA activities generally see HHFA, Ninth Annual Report, Pt. IV (1955).

150 The workable program requirement is not applicable if an urban renewal project was approved for the area before the Housing Act of 1954 became effective. 68 Stat. 623 (1954), as amended, 42 U.S.C.A. \$ 1451(c) (1957).

151 This is for the first $\$ 10,000$ of a new building's value. Section 220 provides that the loan to value ratio may be as low as 70 percent, depending upon the amount of the mortgage, whether new or existing housing is involved, and whether the mortgagor is an owner-occupant or lessor. FHA has adopted the maximum loan to value ratios permitted by statute. 22 Fed. Reg. 6304 (1957).

152 The permissible interest rate has been raised to $5 \frac{1}{4}$ per cent. 22 Fed. Reg. 6290 (1957). At the same time, maximum charges, fees and discounts that mortgagees can collect were imposed. Ibid. 
For Section 221 insurance to be available, a similar workable program requirement exists as for Section 220; the locality (usually this means the mayor) must request that the insurance be provided; and the number of Section 221 insured dwelling units shall not exceed the number certified by HHFA as needed for relocation. ${ }^{153}$ Large-scale rental projects may qualify for Section 221 protection, but to do so, the mortgagor must be a non-profit organization whose rents and profits are legally regulated. Priority to purchase or rent Section 221 housing is given to families who must relocate due to urban renewal or other government action. ${ }^{154}$ If relocating families fail to buy or rent after a reasonable time, the property may be sold or rented to others. ${ }^{155}$ For Section 221 coverage, the insured mortgage may be for as much as 100 per cent of the value of the property (85 per cent if the owner is not the occupant), but cannot exceed $\$ 9,000$ per family unit or single-family dwelling (except that FHA may raise this to $\$ 10,000$ in high cost areas); mortgage maturities cannot exceed 40 years; and interest rates cannot exceed 5 per cent per year unless FHA finds that it is necessary to raise them up to 6 per cent. The advantages of Sections 220 and 221 mortgage insurance over other available federal mortgage insurance ${ }^{156}$ are that the threat of blight in the neighborhood will not be considered by FHA in grant-

I53 "The properties available to eligibles may be found or located within the boundaries of the governmental authority for which the Administrator's Certification of Need has been made. They may also be found or relocated in any community outside those boundaries if within reasonable commuting distance and if a request is made by such community to FHA to extend the benefits of Section 221 mortgage insurance to eligible persons who wish to locate in the community. Such request must come from the chief executive authority of the local governmental entity having primary jurisdiction over the area in which it is sought to have the housing located or in which the existing housing will be purchased. In these cases commitments issued by FHA shall count against the quota established for the community for which the Certificate of Need was made." FHA, Operations Letter No. 231 (August 27, 1957).

154 "What families are eligible for 221 housing? All who have to move because of 'government action.' This has broad coverage: it takes in families from urban renewal areas, both those displaced and those leaving voluntarily. It also includes families removed because of governmental construction, such as highways, public buildings, playgrounds, low-rent housing projects; construction by quasi-public bodies such as state universities; code enforcement; eviction of over-income tenants from low-rent public housing projects." HHFA, 221 Relocation Housing (Dec., 1956). And see HHFA Regional Circular No. 174 (Dec. 29, 1954).

155 ". . . where properties are held for 60 days or more and the builder or seller has made an earnest and diligent effort to find eligible families without success, FHA will permit the properties to be sold to other than eligible families at the same mortgage terms available to eligible families except for conditional commitments issued on existing properties and rehabilitated properties where rehabilitation costs are less than $20 \%$ of the proposed sales price after completion of rehabilitation." FHA, Operations Letter No. 231 (October 27, 1957). Also see FHA, Supplement to Mortgagees' Application for Insurance Under Section 221 of the National Housing Act (form 2004j) for the agreement providing that owners of sale or rental property will for sixty days offer it to eligible families.

${ }^{156}$ The alternative forms of mortgage insurance are principally those provided by FHA under Sections 203 and 207. 48 Stat. 1248 (1934), as amended, 12 U.S.C.A. $\$ 1709$ (Supp., 1957); 48 Stat. 1252 (1934), as amended, 12 U.S.C.A. § 1713 (1957). 
ing insurance, the special assistance FNMA mortgage purchase possibilities, and other somewhat more liberal terms. ${ }^{157}$

The effects of Sections 220 and 221 on the urban renewal program have been disappointing. Up to June, 1957, only 310 mortgages, involving 2,806 dwelling units and amounting to 29 million dollars had been insured under Section $220 ; 158$ and only 108 mortgages, involving 108 dwelling units, and amounting to 900 thousand dollars had been insured under Section $221 .{ }^{159}$ Commitments to insure have been substantially greater. Eventually a large proportion of new housing in urban renewal areas will probably be covered by Section 220 insurance, but Section 220 has not been responsible for much of this housing being built, for almost as satisfactory financing could have been arranged in most cases under other forms of FHA insurance and in some cases without such insurance. The relatively small use of Sections 220 and 221 is due to the limited number of projects that have advanced far enough to qualify for this form of assistance; the lack of builders' profit possibilities in much middle-income housing and nearly all low-income housing $;^{100}$ the delays and uncertainties involved in proceeding under these sections that have discouraged applications; and the tight money market. Use of the sections for rental housing has been further discouraged by FHA restrictions on builders recovering back their venture capital; ${ }^{161}$ the nonprofit organization requirements for mortgagors of rental property; and the low mortgage ceilungs on Section 221 insurance that with present high costs of construction have in effect substantially reduced loan to value ratios. FHA has been unsuccessful in encouraging construction of rental housing since the Section 608 program was terminated. ${ }^{162}$ That program, which aided construction of 464,000

157 E.g., Section 220 coverage of new construction may be based on an estimate of replacement cost rather than appraised value as in Section 203; Section 221 contains a unique provision permitting the mortgagee to assign the mortgage to FHA for debentures if at the end of twenty years the mortgage is not in default; and Section 221 down payments may be only $\$ 200$, but Section 203 requires a minimum down payment of at least 3 percent of the purchase price.

${ }^{158}$ FHA, Monthly Report of Operations 4 (June, 1957). All Section 220 insurance has been of new housing; and 229 of the insured mortgages, involving 299 dwelling units and three million dollars have been home mortgages, the balance have been mortgages on rental housing. Ibid.

159 Ibid. All Section 221 insurance has been for new single-family houses; none of it has been for rental housing. Tbid.

${ }^{160}$ For a study concluding that most middle income families cannot afford to purchase available newly constructed houses or rent available newly constructed apartments, see The National Housing Conference, The Cheapest Houses Available, The Housing Yearbook 5 (1957).

${ }_{111}$ On this problem consult Colean, Impotency of FHA Policies on Apartment Finance, 102 Arch. Forum 110 (June, 1955).

${ }^{162}$ The principal FHA rental housing section is now Section 207. 48 Stat. 1252 (1934), as amended, 12 U.S.C.A. $\$ 1714$ (1957). From the inception of Section 207 in 1935 until June, 1957 , only 77,000 new rental housing units were insured under Section 207. FHA, Monthly Report of Operations 4 (June, 1957).

Grebler, Blank and Winnick conclude that the volume of new rental housing constructed 
rental units during and after World War $\Pi{ }^{163}$ resulted in extensive Congressional investigation of windfall profits and other abuses. ${ }^{164}$ The high profits and other alleged abuses of the Section 608 program have made Congress and FHA fearful of developing a program that would produce a large volume of new rental housing because it might lead to conditions similar to those that developed under the earlier program. These sections have not been successful in providing a substantial volume of either new housing for low-income families or rehabilitated housing, as apparently was expected of them in some quarters when they were passed..$^{165}$

Public housing. In certain respects, Congress has related the public housing program $^{166}$ to urban renewal. Some kind of formal coordination of the two programs is to be expected because of the critical shortage of housing available for

since World War II has been relatively small, but would have been even smaller if liberal FHA aids had not existed. Grebler, Blank and Winnick, Capital Formation in Residential Real Estate 154-55 (1956). They further conclude: "Many factors other than government financial aids have influenced the volume of rental housing construction. Among these are a possible long-term shift in consumers' preferences for single-family houses, fortified by the rise in real income and liquid assets since 1940 and the tax advantages of home ownership; the financial hazards of rental housing construction during a period of rapidly changing costs; and uncertainties over the long-run earning capacity of new projects when rent controls are removed." Id., at 155.

163 HHFA, Eighth Annual Report 6 (1954).

${ }^{164}$ On Section 608 investigations by Congress, see Hearings before the Senate Committee on Banking and Currency on Sen. 2889, 2938, and 2949, 83d Cong. 2d Sess., Pt 3 (1954) (FHA Insurance Provisions); Sen. Rep. No. 1 (Banking and Currency Committee, Report on the FHA Investigation), 84th Cong. 1st Sess. (1955); HHFA Eighth Annual Report 6-7 (1954). FHA has made some recoveries of excess mortgage proceeds distributed in violation of charters of corporations formed under the terms of Section 608. HHFA, Ninth Annual Report 53 (1955).

165 "If middle-income families have so dim a prospect of getting adequate shelter, what is the outlook for their lower-income brethren? Their situation is far worse. None of the efforts made to solve this problem through private construction activity, efforts made by the industry itself and through Government financing aid, have yet provided a solution. Like section 220, the section 221 program of the 1954 act, designed primarily for this purpose, is useless for areas like Philadelphia, because the maximum insurable mortgage amount is $\$ 8,600$, on a house valued at roughly $\$ 9,600$. Even if the terms for 221 insurance were made as favorable as originally proposed by the President's advisory committee, there is considerable doubt as to whether it could be made to serve the purpose intended. The only successful means as yet devised is low-rent public housing, and the number of units so far authorized is wholly inadequate to meet the need." Testimony of Joseph S. Clark, Jr., while Mayor of Philadelphia. Hearings before House Committee on Banking and Currency on H.R. 5827 (Housing Amendments of 1955), 84th Cong. 1st Sess. 157 (1955).

For the anticipated effect of Sections 220 and 221 on low-income housing and rehabilitation of housing see Hearings before Senate Committee on Banking and Currency on Sen. 2889, 2938, and 2949 (Housing Act of 1954), 83d Cong. 2d Sess. 52-60, 71-9, 98-9 (1954); and President's Advisory Committee on Government Housing Policies and Programs Report 14, 47 (1953).

166 Unless otherwise indicated, the term public housing in this article means low-rent federally assisted public housing and does not refer to the Lanham Act, veteran or defense housing administered by PHA. 
low-income families displaced by urban redevelopment projects. ${ }^{167}$ The United States Housing Act of 1937, as amended, provides that in new tenant selection for federally supported public housing, a preference must be given to families which are to be displaced by any public slum-clearance, redevelopment or urban renewal project. ${ }^{168}$ Nor may new public housing be constructed except in localities that have had a workable program approved by HHFA. ${ }^{169}$ The Housing Act of 1954 restricted new public housing to communities in which a federally assisted urban renewal project was being carried out and the new housing had to be necessary for relocation purposes. ${ }^{170}$ This provision was repealed in $1955,{ }^{171}$ following a House committee report that it unduly restricted the public housing program. ${ }^{172}$

Public housing is a PHA administered federal aid program combining federal grants-in-aid and loans. The recipients of federal assistance are local housing authorities. These are public agencies authorized by state enabling acts to construct and operate public housing developments. ${ }^{173}$ All states except Iowa, Oklahoma, Utah and Wyoming have such enabling acts; and of the states permitting them, only Kansas, North Dakota, South Dakota and Vermont do not have federally assisted low-income public housing projects. ${ }^{174}$ Projects also exist in the District of Columbia, Alaska, Hawaii, Puerto Rico, and the Virgin Islands. ${ }^{175}$ As of June 30,1957, 429,000 dwelling units of federally aided public housing in 2100 projects were being operated, 16,000 units more were under construction and 90,000 units were in various pre-construction stages. ${ }^{176}$ Approximately 1.6 million persons were being housed in these projects as of that date. ${ }^{177}$ Public housing is concentrated in states with large urban centers, the Southern states,

167 " . . . Your committee desires to emphasize that no slum-clearance program can successfully proceed without simultaneous provision for an adequate program of low-rent public housing for low-income families, such as provided for in the bill." Report of the Senate Committee on Banking and Currency on Sen. 1070 (Housing Act of 1949), 81st Cong. 1st Sess. 11 (1949).

${ }^{188} 63$ Stat. 423 (1949), as amended, 42 U.S.C.A. $\$ 1410(\mathrm{~g})$ (1957). The preference is also extended to families displaced by any low-rent housing project "or through action of a public body or court, either through the enforcement of housing standards or through the demolition, closing, or improvement of dwelling units. . . ." Ibid.

${ }^{169}$ See p. 337 infra.

17068 Stat. 631 (1954), as amended, 42 U.S.C.A. $\$ 1450$ (1957).

17169 Stat. 638 (1955), as amended, 42 U.S.C.A. \$1451 (1957).

172 Report of the House Committee on Banking and Currency on H.R. Rep. No. 913, 84th Cong. 1st Sess. 18 (1955).

${ }^{173}$ On the constitutionality of state enabling acts pertaining to public housing see Rhyne, Municipal Law § 25-2 (1957).

174 PHA, Ninth Annual Report 25 (1955).

175 Ibid.

176 HHFA-PHA, Statistics Branch, Low-Rent Housing Programs as of June 30, 1957.

${ }^{177}$ Communication from PHA, Statistics Branch (1957). 
and Puerto Rico. ${ }^{178} \mathrm{New}$ York, Pennsylvania, and Illinois are the states with the largest number of units. ${ }^{179}$ Most federally assisted public housing projects have been built by local housing authorities, but some were built by the federal government under such programs as war housing and depression public works and later transferred to local authorities for operation under the low-rent program. ${ }^{180}$ A few cities have rehabilitated and converted private dwellings into public housing. ${ }^{181}$

The volume of new public housing constructed in the past few years has been small due to Congressional cut-backs in the program. In 1949, Congress authorized the construction of up to 810,000 additional public housing units during the next six years. ${ }^{182} \mathrm{~A}$ Senate Committee report on the public housing bill for that year stated: "In the judgment of your committee, this represents a minimum program, considering the acute needs of our under-privileged families."183 The Committee also concluded that substantial government subsidy was needed to provide decent housing to the 30 per cent of urban families with incomes under 2500 dollars a year and that could afford rentals of under 30 dollars a month including heat and utilities. ${ }^{184} \mathrm{By}$ March, 1954, only 178,000 of the public housing units authorized in 1949 , had been constructed or were under construction. ${ }^{185}$ This resulted from Congressional refusal to appropriate funds to fulfill the maximum authorization of the Housing Act of 1949. Since 1954, authorizations of new units have been reduced and now are only 35,000 a year. ${ }^{186}$

New public housing project site selection, land acquisition, construction and financing by local authorities must follow detailed PHA requirements and regulations. ${ }^{187}$ Federal aid to proposed new projects will not be given until the local authority demonstrates to PHA that the new housing will rent for at least 20 per cent less than the rents being charged for decent private low-rent housing avail-

178 PHA, Ninth Annual Report 25 (1955).

${ }^{179} \mathrm{New}$ York, 58,000; Pennsylvania, 34,000; and Illinois, 33,000. But in comparison, Georgia has 24,000; Alabama, 18,000; and Puerto Rico, 23,000. Ibid.

${ }^{180}$ PHA, Ninth Annual Report 7 (1955).

181 Chicago was the first major city to receive federal funds to convert old buildings into low-rent public housing. $12 \mathrm{~J}$. Housing 268 (1955).

18263 Stat. 428 (1949), 42 U.S.C.A. $\$ 1410$ (e) (1957).

${ }^{183}$ Report of the Senate Committee on Banking and Currency on Sen. 1070 (Housing Act of 1949), 81st Cong. 1st Sess. 18 (1949).

184 Id., at 15.

${ }^{185}$ Hearings before Senate Committee on Banking and Currency on Sen. 2889, 2938 and 2949 (Housing Act of 1954), 83d Cong. 2d Sess. 97 (1954).

${ }^{188}$ In 1955 authorizations were set at 45,000 units for one year. 69 Stat. 638 (1955). All but one percent of this authorization was filled. $13 \mathrm{~J}$. Housing 275 (1956). In 1956 there was a statutory authorization of 35,000 units per year for two years. 70 Stat. 1103, 42 U.S.C.A. $\S 1410(\mathrm{i})$ (1957).

${ }^{187}$ PHA, Annual Contributions Contract, Pt. 2 (1955); and HHFA-PHA, Low Rent Housing Manual (1951). For a case study of factors influencing site selection and amount of public housing see Meyerson and Banfield, Politics, Planning and the Public Interest, The Case of Public Housing in Chicago (1955). 
able locally in substantial volume. ${ }^{188}$ PHA assists in financing project plans and construction by loans to local authorities, normally repaid by the sale of local authority temporary notes to private investors during the course of construction. PHA is committed to advance the principal and interest on these notes if at maturity the local authority fails to do so. When a project nears completion, it is permanently financed by the issuance of local authority long-term serial bonds secured by a pledge of PHA annual contributions. These bonds, with interest exempt from state and federal income tax, are sold to private investors. Nearly all long and short term local authority loans are now held by private investors. ${ }^{189}$ The primary financial aid now being given by the federal government to public housing is a subsidy in the form of annual contributions. PHA contracts with the local authorities to make these grants on each project for a period pordinarily of 40 years. Restrictions on tenant eligibility and other conditions of operation are incorporated in these lengthy grant-in-aid contracts. PHA contributions are in an amount sufficient to cover the difference between expenses of operation, including debt service, and the local authorities' rental income. In 1956, federal annual contributions were $\$ 75,000,000 .^{190}$ They need not be repaid unless the projects are sold or operated at a profit. ${ }^{191}$

Annual contributions can be made by $\mathrm{PHA}$ only if the governing body of the locality involved enters into an equivalent elimination agreement with PHA. By this agreement, the locality must assure PHA that unsafe or unsanitary dwelling units in the locality, substantially equal in number to the number of new project units, will be eliminated in the next five years. Elimination may be by demolition, condemnation, effective closing, or compulsory improvement. The requirement does not apply to housing built on a slum-clearance site $;^{192}$ and

18863 Stat. 422 (1949), as amended, 42 U.S.C.A. § 1415(7) (1957). PHA's standards and procedures for administering this section appear in Determination of Lowest Private Rents for Establishing Twenty Per Cent Gap, HHFA-PHA, Low-Rent Housing Manual $\$ 205.6$ (1951).

${ }^{189}$ As of December 31, 1955, local authority loans totaled 2.86 billion dollars, with private investors holding ninety-seven percent of this sum and PHA the remaining three per cent. In 1952, PHA held almost one-half of the outstanding local authority loans. PHA loans were reduced by refinancing long-term government held bonds, increasing private short-term lending opportunities, and by the decline in new project construction that reduced the need for initial government loans. PHA, Ninth Annual Report 16-7 (1955).

190 U.S. Secretary of the Treasury, Annual Report 564 (1956). Annual contributions have increased greatly in recent years. From 1941 to 1953 they totaled only $\$ 116,000,000$. President's Advisory Committee on Government Housing Policies and Programs Report 311 (1953).

${ }^{191}$ Statutory authorizations for PHA local authority loans and annual contributions are 50 Stat. 891,895 (1937), 42 U.S.C.A. $\$ \S 14091410$, 1415 (1957); 63 Stat. 424 (1949), 42 U.S.C.A. $\$ 1421(\mathrm{a})(1957)$.

Also see PHA, Annual Contributions Contract, Pt. 2 (1955), for terms and conditions of annual contributions. Current progress in financing of low-rent public housing is described in PHA, Ninth Annual Report $\$ 2$ (1955).

192 For purposes of equivalent elimination, PHA considers a slum-site to be one in which over half of the land area, excluding streets and alleys, consisted of lots containing unsafe, unsanitary, or overcrowded dwellings. HHFA-PHA, Low-Rent Housing Manual $\$ 206.8$ (1955). 
it may be deferred in areas where there is an acute shortage of decent low-income housing. ${ }^{193}$

No matching funds need be provided for a local authority to receive annual contributions. But a local and state tax exemption subsidy is required. Federal annual contributions will not be paid unless the project is exempted from all local and state real and personal property taxes. ${ }^{194}$ However, the local authority must make a payment in lieu of taxes that ordinarily amounts to 10 per cent of each project's annual rents. ${ }^{195}$

Although local housing authorities select tenants for public housing projects, the tenants must meet eligibility standards set by the federal government. With some qualifications, to be eligible for public housing, a family ${ }^{196}$ must be living in a substandard dwelling, ${ }^{197}$ and have an annual income not exceeding five times the annual rental of the public housing to be furnished it. ${ }^{198}$ Local authorities set schedules of income limits for occupants, subject to PHA approval, ${ }^{199}$ and a spread of 25 per cent is common between maximum permissible income for admission and that for continued occupancy. ${ }^{200}$ As of December 31, 1955 , the median income limit for eligibility (net income after statutory exemptions) for the average size family for admission was $\$ 2700$ a year. ${ }^{201}$ About 29 per cent of all localities had limits of $\$ 2450$ or less, and 33 per cent had limits above

${ }^{193}$ The statutory requirements for equivalent elimination are contained in 50 Stat. 891 (1937), as amended, 42 U.S.C.A. § 1410(a) (1957).

As of June $30,1953,200,000$ substandard dwelling units had been eliminated in accord with the equivalent elimination requirement; seventy-seven percent by demolition, six percent by closing for occupancy, and seventeen percent by compulsory repair. President's Advisory Committee on Government Housing Policies and Programs Report 307 (1953).

For an early article on the subject, see Robinson and Altman, Equivalent Elimination Agreements in Public Housing Projects, 22 B. U. L. Rev. 375 (1942).

194 This restriction is applicable to projects initiated after March 1, 1949. 63 Stat. 428 (1949), as amended, 42 U.S.C.A. $\$ 1410(\mathrm{~h})$ (1957). The earlier act required that a local contribution be made in cash, tax remissions, or tax exemptions equal to twenty percent of the federal contribution. 50 Stat. 891 (1937), 42 U.S.C.A. $\$ 1410($ a) (1946).

19563 Stat. 428 (1949), as amended, 42 U.S.C.A. $\$ 1410$ (h) (1957).

${ }^{196}$ A family is " (a) a group of persons regularly living together which consists of two or more persons related by blood, marriage, or adoption, or (b) a single person sixty-five years of age or over. . . . A group of unrelated persons under sixty-five years of age living together, or a single person under sixty-five years of age does not constitute a family nor may lodgers be included in a family. ..." PHA, Annual Contributions Contract, Pt. 2, $\$ 206(1)$ (1955).

19763 Stat. 422, 423 (1949), as amended, 42 U.S.C.A. $\$ 1415$ (8)(b) (1957).

19850 Stat. 888 (1937), as amended, 42 U.S.C.A. § 1402(1) (Supp., 1957).

19963 Stat. 422 (1949), 42 U.S.C.A. \$1415(8)(a) (1957).

200 PHA, Ninth Annual Report 9 (1955).

${ }^{201}$ Communication from PHA, Statistics Branch. Data for 1955 appears in PHA, Ninth Annual Report 9 (1955). 
$\$ 2950 .{ }^{202}$ Local authorities must make an annual re-examination of each tenant's status to determine continued income and family composition eligibility. ${ }^{203}$

A large percentage of families living in public housing are Negro. ${ }^{204} \mathrm{PHA}$ 's racial policy on project occupancy is contained in this equivocal statement:

The following general statement of racial policy shall be applicable to all low-rent housing projects developed and operated under the United States Housing Act of 1937, as amended:

1. Programs for the development of low-rent housing, in order to be eligible for PHA assistance, must reflect equitable provision for eligible families of all races determined on the approximate volume and urgency of their respective needs for such housing.

2. While the selection of tenants and the assigning of dwelling units are primarily matters for local determination, urgency of need and the preferences prescribed in the Housing Act of 1949 are the basic statutory standards for the selection of tenants. ${ }^{205}$

In large metropolitan centers the demand for public housing is much greater than the supply. ${ }^{206}$ This is also true of most other cities. But in some middlesized and smaller towns there consistently have been unfilled public housing vacancies. This is a little publicized fact, and statistics on the national volume of vacancies are unavailable. One reason for these vacancies is that in some communities white families will not live in projects where there are Negro families and there are not enough eligible Negro families to fill the projects. Also, the increasing percentage of problem families in many projects makes these projects undesirable from the point of view of more "respectable" low-income families eligible for occupancy. Another reason is the poor construction and maintenance quality of some defense housing that has been converted into public housing.

202 Note 200 supra.

${ }^{203} \mathrm{PHA}$, Annual Contributions Contract, Pt. $2, \S 210$ (1955). In the first half of 1955 , four per cent of the families re-examined were found ineligible, PHA, Ninth Annual Report 9 (1955).

204 'Negro families (and a small number of 'other' races) represent about 32 per cent of all families being admitted to and 41 per cent of all families in low-rent public housing, although they are only about 8 per cent of all nonfarm families in the United States. This reflects their lower economic status and greater inability to secure standard private housing within their means." President's Advisory Committee on Government Housing Policies and Programs Report 303 (1953). In June, 1957, eighty percent of the families in Chicago's public housing were non-white.

${ }^{200}$ HHHFA-PEA, Low-Rent Housing Manual, $\S 1021$ (1952). There have been judicia efforts to eliminate segregation practices in the operation of public housing, e.g., Detroit Housing Commission v. Lewis, 226 F.2d 180 (C.A. 6th, 1955).

${ }^{206}$ E.g., in Chicago on June 1, 1957, the public housing vacancy rate was one-tenth of one percent. Chicago Housing Authority Quarterly Report to the City Council (June 30,1957). Vacancies exist due to repair, and cleaning and redecorating at the time of tenant changes. As of June 30,1957, Chicago had 15,410 units of public housing. Ibid. The public housing waiting list was approximately 15,000 at that date. 
Families are reluctant to live in such projects, even at relatively low rentals. Decline in local industrial activity apparently is responsible for vacancies in a few projects.

Public housing rent schedules are set by each local authority, but must be approved by PHA. Rents vary with the location of the project, and size and income of families, but can not be less than one-fifth of net family income. ${ }^{207}$ Including heat and utilities, the median monthly gross rent of families admitted to projects during 1956 was $\$ 35$, and it was $\$ 37$ for those re-examined during that period. ${ }^{208}$ Eighteen per cent of the families living in public housing during 1956 received some form of public welfare assistance. ${ }^{209}$

Existing low-income public housing projects have recently been subjected to considerable adverse criticism, much of it from social workers, government officials, and scholars favorable to public housing. ${ }^{210}$ Fault has been found with the physical character of the projects, including their location. It is claimed that high density-high rise structures are undesirable for families with children. Projects on valuable land and those that replace existing housing have been criticized because they are expensive, require relocation, and destroy dwelling space that is in short supply. The negligible conversion of existing residential properties into public housing has been adversely commented on. Standardized design, together with close landlord regulation of tenants has been condemned as creating an institutional aspect to project living that is rightfully resented by tenants. In many projects, all the tenants are treated as subjects for social work aid, when most of the families do not need this kind of assistance and object to being so treated; although there is evidence that the number of problem families in public housing is increasing, due partly to the priority in new tenant selection given to families displaced from urban redevelopment areas, and that adequate social work resources are not available for these problem families. ${ }^{211}$ Eligibility standards have been criticized as setting too low a maximum on permissible tenant incomes. This excludes a large number of low and middle-income fam-

${ }^{207}$ PHA, Annual Contributions Contract, Pt. 2, § 205 (1955).

${ }^{208}$ Communication from PHA, Statistics Branch. For 1955 data see PHA, Ninth Annual Report 10 (1955).

${ }^{209}$ Note 202 supra.

${ }^{210}$ For criticism of public housing see Report of the Subcommittee on Housing for LowIncome Families, President's Advisory Committee on Government Housing Policies and Programs Report 225 (1953); Bauer, The Dreary Deadlock of Public Housing, 106 Arch. Forum 140 (May, 1957); Churchill, What Changes Must Be Made in Public Housing, 99 Arch. Forum 116 (July, 1953); Wood, Public Housing and Mrs. McGee, $13 \mathrm{~J}$. Housing 424 (1956); Bauer and Yamasaki, High Buildings for Public Housing or Low Buildings, $9 \mathrm{~J}$. Housing 226 (1952); symposium on new ideas in public housing, $8 \mathrm{~J}$. Housing 258-87 (1951); How Much "Selection" Should There Be in Public Housing Tenant Selection, $8 \mathrm{~J}$. Housing 91 (1951); Dunham and Grundstein, The Impact of a Confusion of Social Objectives on Public Housing: A Preliminary Analysis, 17 Marriage and Family Living 103 (1955); Baratz, Public Housing: A Critique and a Proposal, 20 Soc. Res. 332 (1953).

211 Wood, Public Housing and Mrs. McGee, 13 J. Housing 424 (1956). 
ilies, especially those of minority racial groups, for whom decent private housing is unavailable. It also weakens the over-all caliber of occupancy by disqualifying many of the more energetic families and increasing the proportion of problem families. This lowers the reputation of public housing and increases tenant frictions and management problems. Eligibility standards are also under criticism for failing to provide for the housing needs of more extreme problem families who otherwise are qualified.

\section{Procedures for Securing Redevelopment Project Am}

The workable program. In order for a locality to qualify for redevelopment project aid from the federal government, it must have a workable program for elimination and prevention of blight. This requirement was first made by the Housing Act of 1954; and is also a condition precedent to Sections 220 and 221 mortgage insurance and federal low-rent public housing grants and annual contributions. ${ }^{212}$ It does not apply to transactions entered into prior to the 1954 act.

The statutory description of what a workable program must contain is vague and brief. ${ }^{213}$ HHFA has amplified the statutory description with instructions that set out under seven headings the fundamentals of a workable program and include most of the prevalent techniques for local government planning and regulation of urban land use. ${ }^{214}$ The seven workable program fundamentals are these:

(1) Housing and building codes. The objective of this requirement is to "assure adequate minimum standards of health, sanitation, and safety through a comprehensive system of codes and ordinances which state the minimum conditions under which buildings may be lawfully occupied."215 Attention is called to some of the model codes that have been prepared, and although HHFA recog-

21268 Stat. 623 (1954), as amended, 42 U.S.C.A. \$ 1451(c) (1957). The workable program requirement as applicable to public housing was deleted in 1955, 69 Stat. 638 (1955); but it was reinserted in 1956, 70 Stat. 1103 (1956).

213 " [A] workable program [is a program] (which shall include an official plan of action, as it exists from time to time, for effectively dealing with the problem of urban slums and blight within the community and for the establishment and preservation of a well-planned community with well-organized residential neighborhoods of decent homes and suitable living environment for adequate family life) for utilizing appropriate private and public resources to eliminate and prevent the development or spread of, slums and urban blight, to encourage needed urban rehabilitation, to provide for the redevelopment of blighted, deteriorated, or slum areas, or to undertake such of the aforesaid activities or other feasible community activities as may be suitably employed to achieve the objectives of such a program. ..." 68 Stat. 623 (1954), as amended, 42 U.S.C.A. \$ 1451(c) (1957).

211 These instructions appear in a circular that is used by localities in preparing workable programs and by HHFA in evaluating them. HHFA, How Localities Can Develop a Workable Program 5-11 (as revised, Dec. 1956). A somewhat similar circular has been prepared for aid in the preparation and evaluation of workable programs by communities with populations under 5,000. HHFA, Workable Programs for Small Communities and Rural Non-Farm Areas (Nov., 1956).

215 HHFA, How Localities Can Develop a Workable Program 5 (as revised, Dec., 1956). 
nizes that housing and building codes may vary due to local conditions, the model codes are apparently cited as generally acceptable guides. ${ }^{216}$

- (2) A comprehensive community plan. The term general plan is used by HHFA synonomously with comprehensive community plan. ${ }^{217}$ Its minimum requirements are a program for physical development that shall include land use, thoroughfare, and community facility plans; a public improvement program; a zoning ordinance; and subdivision regulations. ${ }^{218}$

(3) Neighborhood analyses. These analyses are designed to identify "the extent and intensity of blight and logical patterns of neighborhoods for purposes of developing a basis for planning of healthy neighborhoods of decent homes and suitable living environment."219 In carrying out this phase of the workable program, HHFA believes that a city should make surveys to determine the location and character of its blighted areas, identify the causes of deterioration, and delineate residential neighborhoods for clearance or other remedial action. ${ }^{220}$

(4) Administrative organization. This requirement entails adequate personnel and programs for code enforcement, ${ }^{221}$ slum prevention, and urban renewal. Adequate legal authority should exist to carry out these programs and to contract with the federal government in doing so.

(5) Financing. The city must show that it has the financial capacity to carry out its workable program and its grant-in-aid share of urban renewal projects.

(6) Housing for displaced families. The significance that HHFA attaches to relocating those displaced by government action, especially slum clearance, is accentuated by making it a separate workable program requirement. If exten-

${ }^{216}$ Id., at 6. Examples of model codes cited are the American Public Health Association, A Proposed Housing Ordinance; HHFFA and U.S. Dept. of Commerce, Report of the Coordinating Committee for a National Plumbing Code; and National Fire Protection Association, The National Electrical Code. HHFA also has prepared a monograph to aid cities desirous of improving their housing codes. HHFA, Local Development and Enforcement of Housing Codes (1953). The monograph discusses standards and administration; describes the "Baltimore Plan" for slum rehabilitation; and sets out parts or all of the Baltimore, Milwaukee and St. Louis housing ordinances as illustrations of good codes.

${ }^{217}$ HHFA's workable program instructions refer to the comprehensive community plan as a general plan. HHFA, How Localities Can Develop a Workable Program for Urban Renewal 7 (1956). Also, HHFA's description of requirements for a Section 105(a) general plan are substantially the same as for a workable program comprehensive community plan. Section 105(a) of the Housing Act of 1949, as amended, provides that redevelopment project loan and grant contracts shall require a general plan to which the project plan conforms. 63 Stat. 416 (1949), as amended, 42 U.S.C.A. $\$ 1455$ (a) (1957).

${ }^{218}$ An HHFA monograph describes types of subdivision regulations that the agency considers adequate. HHFA, Suggested Land Subdivision Regulations 9-35 (1952). It was developed as an aid to localities, and contains a helpful bibliography.

${ }^{219}$ HHFA, How Localities Can Develop a Workable Program for Urban Renewal 7 (1956).

${ }^{220}$ An HHFA monograph is available to aid localities in making housing surveys. HHFA, How to Make and Use Local Housing Surveys (1954).

${ }^{221}$ An HHFA monograph has been prepared to facilitate local code enforcement activity. HHFA, A Report on Administrative Procedures for Enforcement of Building Regulations (1954). 
sive displacement activity is contemplated, HHFA admonishes localities to plan adequate relocation housing and to give particular attention to rehousing displaced minority group families.

(7) Citizen participation. The purpose of this requirement is to secure participation by community and neighborhood groups so as to increase the likelihood that the workable program will be supported and carried out, and so that local objections to it will be made and adjusted at an early stage. The formation of a citizens advisory committee is suggested by HHFA as one means for achieving this participation, ${ }^{222}$ and it is required by some state enabling acts. ${ }^{223}$ The usual citizenship participation has been by such groups and individuals as local business organizations, including chambers of commerce and realtors associations, service clubs, unions, and prominent citizens of respected standing.

The localities are obligated by statute to submit workable programs to HHFA for approval. ${ }^{22}$ In its approvals, HHFA has been very lenient, ${ }^{225}$ which the legislative history of the Housing Act of 1954 seems to justify. ${ }^{226} \mathrm{~A}$ mere showing of progress toward achieving the seven-point set of fundamentals has often been enough for approval, and many small cities have been approved on nothing more than declarations of good intentions to start developing a workable program in the immediate future. To encourage continuing progress, agency approval of workable programs is given for a one-year period only, following which recertification for another year will be given if the agency is satisfied with the progress made or the type of workable program then in effect. ${ }^{227}$ Recertifica-

222 HHFA, Local Public Agency Letter No. 24 (Sept. 29, 1953).

${ }_{223}$ E.g., Ore. Rev. Stat. (1953) c. $457, \S 457.100$.

22463 Stat. 416 (1949), as amended, 42 U.S.C.A. $\$ 1455$ (a) (1957).

${ }_{225}$ This leniency extends to the general plan so far as workable program approval is concerned. But a general plan is also required by Sections 105 (a) and 110(b) of Title I, 63 Stat. 416, 420 (1949), as amended, 42 U.S.C.A. \$1455(a) (1957); 68 Stat. 626 (1954), as amended, 42 U.S.C.A. \$1460(b) (Supp., 1957). When submitted under these sections, HHFA insists on the general plan being more complete than the minimum sufficient for workable program approval. The general plan requirement of section 105(a) precedes that for a workable program, having been in the act since 1949. Its essentials are discussed in HHFA, Local Public Agency Manual, Pt. 2, c. 2, \$§ 2, 4 (1955).

226 'This workable program requirement is not intended to apply a strait jacket to communities. From those cities more advanced more should be expected. From those cities just beginning this long road to removing slums and blight and to preventing it through realistic codes and aggressive enforcement, there should be full understanding of the time and effort it takes to develop and to put into effect a full-scale local attack. ... The workable program requirement seeks a bona fide and practical expression of the community's own projected program to deal with its own problems, presented in good faith and with the firm resolve to carry that program through to accomplishment." Report of the Senate Committee on Banking and Currency on Sen. 1472 (Housing Act of 1954), 83d Cong. 2d Sess. 37 (1954). Also see testimony of HHFA Administrator Cole. Hearings before the Senate Committee on Banking and Currency on Sen. 2889, 2938 and 2949 (Housing Act of 1954), 83d Cong. 2d Sess. 97 (1954).

${ }^{327}$ The limited character of original certifications appears in the formal Workable Program Determination and Certification issued to a locality when its workable program is approved. 
tion is not required for federal aid to be continued that was contracted for prior to the expiration date of the workable program.

As of May 31, 1957, 238 workable programs had been approved by HHFA, 77 had been recertified, and 159 additional cities were preparing workable program data for submission to the agency or their submissions were under consideration. ${ }^{228}$ Many of the approved programs have been submitted by small towns, mostly in the South, that are only seeking to qualify for public housing. ${ }^{29}$ Since the workable program requirement has been in effect, the Washington office of HHFA has rejected only one workable program and only a few have been rejected by the regional offices that screen them before they are finally submitted to the national office for final approval. ${ }^{230}$

In small cities and some middle-sized ones, the workable program requirement has had a great effect, even as leniently administered by HHFA, in creating local government land use planning and regulation. In large cities the requirement has generally had little effect. Nearly all large cities already had plans, programs, and personnel of the kind required by the seven-point set of HHFA workable program fundamentals. The workable programs submitted by most large cities consist of a brief textual statement summarizing local compliance with each of the seven fundamentals, followed by many exhibits that include copies of statutes, ordinances, local government agency reports, plans and maps. ${ }^{231}$

If HHFA insisted on approving only those workable programs that showed full compliance with the agency's seven fundamentals, the impact of federal power on local government through urban renewal might be even greater than it is. But for several reasons HHFA has apparently chosen not to push the potential inherent in this grant-in-aid condition. Most important, Congress might not tolerate such efforts. Also, the proponents of urban renewal have desired that clearance and redevelopment take place as rapidly as possible, and strict application of workable program requirements would seriously delay project achievements. Nor are there available today enough qualified planners to carefully and fully prepare workable program plans and surveys for all the cities wishing to

228 HHFA, Office of the Administrator, Workable Program Approvals as of May 31, 1957.

${ }^{229}$ Of the 238 workable programs approved, 109 were for cities in Alabama, Georgia, Tennessee and Texas. Ibid.

${ }^{230}$ The original workable program submissions are retained by the regional offices and summaries are sent to the Washington office where they are duplicated and available for limited distribution.

${ }^{231}$ For example, the New York workable program comprises a 7-page printed letter of the Mayor to the HHFA Administrator, supported by 45 exhibits; the Chicago program of a 53page report supported by 100 exhibits, and the Philadelphia program consists of a 37-page mimeographed report, supported by 121 exhibits. Mllustrative of a carefully prepared workable program that reflects substantial progress resulting from the requirements of both the workable program and the urban renewal loan and grant program is that of New Haven, Connecticut. The text portion of many workable program submissions have been duplicated by the localities and are available for limited distribution. 
qualify for federal urban renewal assistance. ${ }^{232}$ Finally, many cities most in need of federal urban renewal aid might reject it if they had to meet extremely high standards of city-wide planning and land use regulation. These same reasons seem to explain why the workable program fundamentals ignore several of the most troublesome problems in urban renewal and blight prevention: coordinated land use planning and regulation for the entire metropolitan area, racial segregation, and public mass transit.

Loan and grant procedure. A complex set of procedures has been developed by HHFA for administration of loans and grants for urban redevelopment projects. ${ }^{233}$ Involved local public agency plans, applications, and reports are required, facilitated by the extensive use of HHFA forms. Regulation of local public agency activity by HHFA is close and extremely detailed. ${ }^{234}$ In addition

${ }^{232}$ Considerable support has existed for the creation of federal fellowship or training funds to increase the number of qualified urban planners. Sen. 1,230, 85th Cong. 1st Sess. (1957); Hearings before Subcommittee of the Senate Committee on Banking and Currency on Housing Amendments of 1957, 85th Cong. 1st Sess. 602-3, 630, 758, 800-801 (1957).

${ }^{233}$ The major procedural steps required by HHFA from the beginning to the end of an urban redevelopment project, assuming that the usual loan and grant assistance is sought, are these: (1) submission to HHFA by the local agency of an application for survey and planning funds, with extensive supporting documentation; (2) after approval of the application by HHFA, execution of a contract for planning advance between the local agency and HHFA; (3) preliminary survey and planning work by the local agency culminating in a lengthy and detailed preliminary project report to HHFA; (4) after approval by HHFA of the preliminary project report, issuance to the local agency of a statement of continued obligation under contract for advance; (5) final survey and planning work by the local agency; (6) submission by the local agency to HHFA of a final project report and application for loan and grant, the final project report to contain among other documentation separate project plans for redevelopment, land acquisition, land disposition, property management, and financing; (7) a general plan, to correspond with the urban renewal plan must be submitted by the time the final project report is submitted; (8) after approval by HHFA of the final project report, submission by the local agency of local project approval data; (9) the workable program must be submitted and approved before a loan or grant contract can be entered into; (10) after approval of the application for loan and grant, execution of a contract for loan and grant; (11) execution of land acquisition plan, including eminent domain takings; (12) management of acquired properties; (13) execution of the relocation plan, with submission of periodic reports and a final relocation report to URA; (14) execution of a site preparation plan, following HHFA bidding. contract, and insurance procedures; (15) execution of the land disposition plan, including approval by HHFA of proposed redeveloper and sale terms; (16) HHFA final project audit. Many minor record keeping and reporting procedures are required. Most plans, applications and reports must be extensively documented. Most procedures to be followed by local public agencies are set forth in the two volume HHFA Local Public Agency Manual; and many of them are required by contracts of planning advance, loan or grant between the local public agencies and $H H F A$, and are described in these contracts.

234 An example of the detail required by HIHFA in local agency reporting are these essentials of the redevelopment plan and supporting documentation that must be submitted to HHFA, taken verbatim from the HHFA, Local Public Agency Manual, Pt. 2, c. 5, $\$ 2$ (1955):

\section{"THE REDEVELOPMENT PLAN}

\section{"SUPPORTING DOCUMIENTATION}

"A. Description of Project Area

"A project boundary map and legal de-

scription of the project area which estab-

lishes the perimeter of the project, clearly 
to administration of control over these agencies by elaborate reporting requirements, HHFA personnel does frequent field consultation and inspection work. Field work is done mostly by HHFA field representatives, one of whom is assigned to each project. The field representatives also do much of the actual regional office review and approval work for the projects to which they are assigned. ${ }^{235}$

Not only is HHFA personnel regulated by statute and internal agency requirements in administering loan and grant procedures, but lengthy contracts between HHFA and the local public agencies obligate the local agencies to comply with many of the procedures. In the usual case, two such contracts are en-

The Redevelopment Plan-Continued

defines the limits of all parcels or areas within this perimeter not to be acquired but which are to be subject to the redevelopment plan controls and restrictions, and also clearly delimits those parcels or areas which are specifically to be excluded from the project area and therefore from the Redevelopment Plan.

"B. Planning Proposals

2. Right-of-Way Adjustment Plan

3. Zoning Plan

4. Regulations and Controls to $\mathrm{Be}$ Applied

"C. Relationship of the Redevelopment Plan to Local Objectives

"1. Statement on Conformance to General Plan

2. Statement on Relationship to Definite Local Objectives

"D. Site Preparation Plan

"1. Sanitary Sewer Plan

2. Storm Drainage Plan

3. Water System Plan

4. Plan for Other Publicly Owned Utilities

5. Private Utility Adjustments Plan

6. Major Grading and Special Site Improvement Plan

"E. Other Provisions Necessary To Meet

State and Local Requirements

"Additional maps, documents, or state-

$$
\text { [Footnote } 234 \text { continued on p. 343] }
$$

${ }^{235}$ The duties of field representatives are described id., at Pt. 3, c. $1, \S 3$ (1955).

"Description and Justification of the Project Area Plan

Report on Economic Soundness of Project Area Plan

Illustrative Site Plan

Neighborhood (or District) Plan

Neighborhood (or District) Zoning Plan

Description of Relationship of Project Area Plan to Neighborhood (or District) Plans

"Demolition and Clearance Plan

Utilities Plans Detailed

Street Improvement Plan

Description and Justification of the Preparation Plan

Site Preparation Cost Estimate

Approvals of Modifications of Utilities and Other Facilities 
tered into: a contract of planning advance and a loan and capital grant contract. These are standardized agreements prepared by HHFA and set forth the terms under which federal funds will be made available. The amount of the federal capital grant is specified in the contract, but may be supplemented later if original cost estimates prove to be greater than anticipated. Subsequent increases have been common because project delays, changes in project plans, incomplete planning, and rising construction costs have resulted in original estimates frequently being too small.

The loan and grant contract gives the federal government lien and pledge rights in unexpended funds held by the local public agency, including loan and grant funds and proceeds from sales of project lands. This lien is to secure repayment of federal project loans. The contract also gives the federal government the right to have a receiver appointed if the local agency defaults in its loan repayments, the receiver to administer the project and take possession of project land and other assets. Another section of the loan and grant contract requires the local public agency to obligate redevelopers and their assignees to use project

[Footnote 234 continued from p. 342]

ments required by or under State or local

law to be included in the Redevelopment Plan.

"F. Official Actions

"Statement of measures required to be taken by State or local official agencies to enable the proposed Redevelopment Plan to be realized.

"G. Changes in Approved Plan

"Description of Measures to Realize the Redevelopment Plan. Description of all legislative and other measures (including zoning, subdivision, building, and other regulations) proposed for adoption, authorization, approval, change, addition, amendment, or enforcement; and the steps which have been or will be taken to procure necessary government action. Assurances by providing entity, or other evidence, that facilities outside of the project area necessary to support the new uses will be provided. (See Part 2, Chapter 10, Section 8.) Identification of boundaries of fire, school, and other districts within and adjacent to project area. Statement of proposal for consulting with local planning agency on Redevelopment Plan. Statement of proposal for submitting Redevelopment Plan to local governing body for approval.

Identification of public body to conduct hearing; proposed time and place; and proposed method of giving public notice of hearing, including form, content, and timing of publication.

"Provisions for amending or making changes in the Redevelopment Plan after its approval by the local governing body." 
land in accord with the urban renewal plan, and to complete within a reasonable time improvements required by the plan. As yet the federal government has had no occasion to enforce any rights it may have against redevelopers who fail to comply with these requirements.

No land can be acquired by a local public agency for an urban redevelopment project until after a public hearing is held. ${ }^{236}$ The hearing is designed to aid the local public agency in determining whether or not the particular tract should be acquired for renewal. Opponents of the project are given an opportunity to testify at these hearings. In some states, the hearings have been used to make a record for use in possible litigation seeking to invalidate projects under state enabling laws.

Title to land in renewal projects is taken in the name of the local public agency. Land may be acquired by direct negotiation with the owners without use of eminent domain proceedings or eminent domain proceedings may be used. HHFA must approve the filing of eminent domain proceedings and must approve the price limits within which the local public agencies will offer to buy any land in project areas. ${ }^{237}$ If the courts find that the eminent domain taking is for a public purpose, then the size of the project area, its boundary lines, and the title rights taken are questions within the discretion of the legislature which the courts will not review. ${ }^{238}$

The cost of land acquired for urban redevelopment projects may depend in part on the nature of local land use regulation. The value of blighted land tends to be much higher if local regulation permits maximum possible land exploitation. For example, in blighted areas, higher rents, higher appraisals, higher market prices, and higher eminent domain awards are likely if zoning regulations permit almost any kind of land use, if housing codes permit crowding of dwelling units, or if building codes permit poor construction and maintenance. The same results are likely if effective land use regulations exist but are not enforced; although there is authority that when land is taken for a public purpose, such as urban redevelopment, the owners need not be compensated for value caused by illegal use. ${ }^{239}$ If a locality plans its urban redevelopment projects far enough in advance, land acquisition costs can frequently be reduced by early passage or enforcement of effective land use regulations. ${ }^{240}$

${ }^{236} 63$ Stat. 417 (1949), 42 U.S.C.A. $\$ 1455$ (d) (1957). The desired ends that these hearings should serve are discussed in Sullivan, Administrative Procedure and the Advocatory Process in Urban Redevelopment, 45 Calif. L. Rev. 134 (1957).

${ }^{237}$ HHFA, Local Public Agency Manual, Pt. 2, c. 7, § 1 (1955).

238 Berman v. Parker, 348 U.S. 26, 35 (1954); Starr v. Nashville Housing Authority, 145

F. Supp. 498 (M.D. Tenn., 1956).

${ }^{239}$ Orgel, Valuation Under Eminent Domain $\$ \$ 32,33$ (2d ed., 1953).

240 HHFA recognizes this. "Inordinately high cost for real estate acquisition in slum or blighted areas may result from deficient appraisals, faulty land acquisition methods, strained relations with site owners and occupants, overzoning, unrealistic tax assessment practices, 
Once land is acquired by a local public agency, months and even years may pass before a redeveloper starts construction. This time is taken up in relocating occupants, preparing the site for redevelopment, securing a redeveloper, and planning and financing by the redeveloper. Iitigation may also cause delay. In this intervening period, the local public agency manages the project land..$^{241}$ This usually means acting as landlord to hundreds of tenants until they are relocated, and then demolishing buildings. Rents are retained by the local public agencies. Only in New York City has HHFA permitted redevelopers to clear land or relocate occupants. ${ }^{242}$ In that city, redevelopers also may collect and keep rentals prior to relocation, which may have the effect of reducing net project costs.

After relocation and site preparation, the usual practice is for the local public agency to sell the land it has acquired, although lease of the land is permitted. Both the contract and conveyancing instruments must be approved by HHFA, as must the price. Similar approval is required of the purchaser's financial responsibility and his qualifications for organizing, constructing and operating the project. ${ }^{243}$ In most instances, private redevelopers are the purchasers. In some instances, one redeveloper has assumed responsibility for developing an entire urban renewal area; in others, many redevelopers have participated, each taking responsibility for part of the area. Option or other contracts of sale are never made until after the local public agency has acquired title to the land, even though negotiations with redevelopers may start early in the project planning stage. A tentative "understanding," but one not legally binding, may have been reached between the local agency and redevelopers long before the redevelopers buy the land, with HHFA kept fully informed of what has transpired. Extensive planning work is often done by redevelopers at this preliminary stage. Under some circumstances, land sales to private redevelopers must be by com-

failure of the local government to enact or to enforce adequate housing codes, or from a combination of such influences. ... The removal [of some of these causes depends on] ... the modernization and improvement of zoning regulations and the enactment and enforcement of housing codes providing adequate minimum standards governing the occupancy of structures for dwelling purposes. Such measures not only promise long-term protection of the community from future blight, but also provide the more immediate benefit of alleviating a prominent cause of excessive payments for the acquisition of slum real estate." HHFA Local Public Agency Manual, Pt. 2, c. 7, \& 1, p. 2 (1955).

On causes of excessive urban renewal land cost, see also Colean, Renewing Our Cities, 149-53 (1953).

24 Management procedures are discussed in Jenkins, Management of Slum Sites in Urban Redevelopment, National Association of Housing and Redevelopment Officials, Redevelopment Information Service, Service Publication No. 7 (1953).

${ }^{212}$ The exceptional treatment of New York was made at the insistence of New York City officials and has been one cause for considerable friction over urban renewal between these officials and HHFA. $13 \mathrm{~J}$. Housing 100, 214 (1956). Much of the friction has centered on the large Manhattantown relocation. See note 264 infra.

${ }^{213}$ HHFA, Local Public Agency Manual, Pt. 3, c. 6, § 4 (1955). 
petitive bidding. ${ }^{244}$ Because of the delay and uncertainty faced by private redevelopers and the cost of their estimates and plans for projects that may never be approved, large redevelopers have an advantage over small ones. Only redevelopers with substantial financial backing can usually afford to assume the risks inherent in these projects. ${ }^{245}$ This is particularly true of projects in big cities and those involving new buildings of considerable size. Several large private companies are increasingly active nationally in the redevelopment of urban renewal areas. This is a new trend in residential and commercial construction. ${ }^{246}$

To discourage speculation, the redeveloper may sell the land prior to completion of the improvements'only if the new purchaser is qualified, if he assumes the obligations of the original redeveloper, and if the original redeveloper is not released from his obligations until redevelopment improvements have been properly completed. ${ }^{247}$ Nor can redevelopers speculate in project areas prior to land clearance. This is prevented by the local public agencies retaining responsibility for relocation and clearance.

Relocation. 'The relocation of families displaced by urban redevelopment projects is one of the most troublesome problems in urban renewal. It has also been a problem to government agencies where slum housing has been replaced by public housing projects or by such public improvements as new traffic arteries. ${ }^{248}$ Congress has sought to assure adequate family relocation from urban redevelopment areas by providing that loan or grant contracts with local public agencies contain requirements that feasible methods exist for temporary relocation of displaced families and that decent housing be made available to such families at rents or prices within their means and reasonably accessible to their places of employment. ${ }^{249}$ These provisions have been strengthened by the statutory requirement that in tenant selection for federally supported public housing, priority be given to families displaced by urban renewal projects. ${ }^{250}$ They have also been strengthened by a statute permitting local agencies to pay displaced families up to 100 dollars each for moving expenses, or in lieu of such expenses, with

214 Id., at $\S 3$ and Local Public Agency Letter No. 84 (Dec. 21, 1956).

${ }^{245}$ The types of businesses and institutions that are financing redevelopment projects or showing interest in doing so are discussed in Redevelopment: Pt. I, Financing, 14 J. Housing 316 (1957).

${ }^{240}$ The business methods of Webb and Knapp, the largest of the national redevelopers, are discussed in 79 Forbes 15-19 (May 1, 1957).

247 HHFA, op. cit. supra note 243. See also 63 Stat. 417 (1949), as amended, 42 U.S.C.A. $\S 1455$ (b) (1957).

${ }^{248} \mathrm{PHA}$ will not approve a site for new public housing that involves the displacement of site residents unless a feasible plan for relocation is developed by the local authority and it agrees in the annual contributions contract to carry out the relocation plan. HFFA-PHA, Low Rent Housing Manual $\$ 209.1$ (1955); and PHA, Annual Contributions Contract, Pt. 2, 104 (1955).

${ }^{249} 63$ Stat. 417 (1949), as amended 42 U.S.C.A. § 1455(c) (1957).

${ }^{250}$ Note 168 supra. 
federal grants covering the full amount of these expenditures. ${ }^{251}$ HHFA has sought to further assure adequate local public agency relocation efforts by making adequate housing for displaced families a workable program essential, ${ }^{252}$ and by imposing detailed requirements for local agency relocation plans and their execution. ${ }^{253}$ HHFA considers that an effective local government relocation program entails a relocation office in or near the project area; a family-by-family survey of the area to determine relocation needs and qualifications; family interviews to discuss rehousing possibilities; concerted efforts to find adequate housing vacancies; inspection of housing that site occupants find unassisted, with offers of relocation aid if that housing is not "decent, sanitary and safe"; and the use of eviction proceedings only as a last resort.254 $\mathrm{A}$ few cities, including Philadelphia, Chicago, and Cincinnati, have created central relocation agencies to take care of relocation from all kinds of government projects that displace families. 255

By mid-1957, about 125,000 families had been displaced or were scheduled to be displaced by then-approved federal urban redevelopment projects. ${ }^{256}$ Fiftyeight per cent of them were non-white. ${ }^{257}$ A majority of the families located in redevelopment project areas is eligible for public housing ${ }^{258}$ and the percentage is higher for non-white than white families. ${ }^{259}$ Racial segregation in urban hous-

23170 Stat. 1100 (1956), as amended, 42 U.S.C.A. $\$ 1456(f)$ (Supp., 1957). Prior to this section being passed, HHFA approved direct financial assistance to families moving from renewal sites. HHFA, Local Public Agency Manual, Pt. 2, c. 6, $\$ 5$ (1955). HHFA rules for relocation payments authorized by federal statute appear in 21 Fed. Reg. 9991 (1956), as amended by 22 Fed. Reg. 1980 (1957).

See Relocation Payments Under Section 106(f) of Title 1, HHFA, Local Public Agency Letter No. 80 (October 8,1956 ). The provision for payments in lieu of moving expenses, added to Section $106(\mathrm{f})$ by the Housing Act of 1957, apparently permits payments to be made without vouchers or other proof of the actual expenses. Hearings before Subcommittee of the Senate Committee on Banking and Currency on Housing Amendments of 1957, 85th Cong. 1st Sess. 93 (1957). Bonus payments have been used in New York to induce families to move from slum clearance areas. In 1949-50, the New York City Housing Authority paid $\$ 75,000$ to 182 families as bonuses to move from one relocation site. Meltzer, Relocation of Families Displaced in Urban Redevelopment; Experience in Chicago, in Urban Redevelopment: Problems and Practices 405, 437 (Woodbury ed., 1953).

252 P. 337 supra.

${ }^{253}$ HHFA, Local Public Agency Manual, Pt. 2, c. 6 and Pt. 3, c. 4 (1955).

251 Ibid.

${ }^{255}$ Arguments for and against a central relocation agency, with particular reference to Washington, D.C., are discussed in Centralized Relocation, 14 J. Housing 234 (1957).

${ }^{256}$ HHFA, Urban Renewal Project Characteristics 8 (June 30, 1957).

${ }^{257}$ Ibid. This non-white calculation omits consideration of Puerto Rican projects. Id., at 4.

${ }^{258}$ As of June 30, 1957, data for 266 out of 272 projects approved for final planning or execution showed that fifty-eight per cent of the families relocated or to be relocated were eligible for public housing. Id., at 8 .

${ }^{259}$ As of September 30, 1953, approved project areas in continental United States contained 35,500 non-white families, sixty per cent of them eligible for public housing, but only 19,500 white families, of which forty-four per cent were eligible for public housing. President's Advisory Committee on Government Housing Policies and Programs Report 186-87 (1953). 
ing makes the relocation of non-whites particularly difficult, ${ }^{260}$ especially as most such families requiring relocation are low-income, and even with public housing, ${ }^{261}$ there is a critical shortage of low-income dwelling units. The problem is made more difficult by the higher rents that Negroes must pay than those paid by whites for comparable housing. ${ }^{262}$ Nor is eventual relocation back into the project area possible, except in rare cases, because redevelopment is often not residential, and seldom low-income residential. ${ }^{263}$ Relocation has accelerated competition for an already inadequate supply of low-income housing. ${ }^{264}$

Residential occupants of renewal areas do not present the only relocation problems. Business occupants, particularly small retail stores, also present problems. A business that must relocate may be seriously damaged in loss of good will, it may have to close down for months until adequate new quarters are located and available, and moving costs may be substantial. Eminent domain awards normally do not compensate for these kinds of losses; $;^{265}$ and the average

260 "No examination of today's housing needs can be complete without consideration of the special problems of minority groups, which cut across all income levels. We are not happy to detail the situation that exists in Philadelphia, but it serves to illustrate what holds true in many, many other places. Of our more than 2 million citizens, over 400,000 are Negroes, and almost half of them live in areas scheduled for redevelopment as compared with less than oneeighth of the white families. Even for those non-white families who could afford to buy or rent better homes, the possibility of doing so is very small. Private housing, finance, and real estate practices, as well as continued prejudices severely limit areas where Negro families may live. Sharply illustrative of the problem is the fact that, from 1946 to 1953 , a total of 140,000 private dwelling units were newly built in the Philadelphia metropolitan area, but only a little over 1,000 of them were available for Negro occupancy." Testimony of Joseph S. Clark, Jr., then Mayor of Philadelphia. Hearings before House Committee on Banking and Currency on H. Rep. No. 5827 (Housing Amendments of 1955), 84th Cong. 1st Sess. 157 (1955). See also Nesbitt, Relocating Negroes from Urban Slum Clearance Sites, 25 Land Economics 275 (1949).

${ }^{261}$ The annual turn-over rate for public housing is substantial. For example, it is ten to twelve per cent in Washington. Rouse and Keith, No Slums in Ten Years, Washington Workable Program 24 (1955); eleven per cent in Boston, Boston Workable Program 4-6 (1955); eighteen per cent in New Haven, New Haven Workable Program 37 (1957); and thirty-two per cent in Norfolk, Norfolk Workable Program 27 (1957). In the decade prior to 1953, the annual national rate rose from fifteen per cent to twenty-six per cent. President's Advisory Committee on Government Housing Policies and Programs, Report 305 (1953). Negro families stay in public housing substantially longer than white families. Ibid.

Those displaced by urban renewal projects do not have exclusive preference rights in public housing vacancies. 63 Stat. 423 (1949), as amended, 42 U.S.C.A. $\$ 1410(\mathrm{~g})(1957)$.

${ }^{262}$ Data comparing Negro and white rentals is sketchy. The apparent differential may be due to the steady increase in the Negro population of many cities, and may exist only in cities where this migration has been heavy. Becker, The Economics of Discrimination 57-62 (1957).

263 P. 321 supra.

${ }^{264}$ Meltzer, Relocation of Families Displaced in Urban Redevelopment: Experience in Chicago, in Urban Redevelopment: Problems and Practices 405, 452 (Woodbury ed., 1953). Although it concentrates on Chicago's experience, this study is the best recent discussion of relocation. On relocation in Chicago, see also Chicago Housing Authority, Relocation of Site Residents to Private Housing, The Character and Quality of Dwellings Obtained in the Movement from Chicago Housing Authority Slum Clearance Sites, 1952-1954 (1955). Relocation problems in New York are discussed in New York State Division of Housing Report 89 (1956).

${ }^{265}$ Banner Milling Co. v. State, 240 N.Y. 533, 148 N.E. 668 (1925), no award for loss of good will; St. Louis v. St. Louis I. M. \& S. Ry. Co., 260 Mo. 694, 182 S.W. 750 (1916), no award for 
small retailer, being a short-term lessee, is ordinarily not entitled to eminent domain compensation for loss of his lease when it is taken for redevelopment. ${ }^{266}$ Furthermore, slum-area retailers are sometimes incompetent to relocate without help because of their limited business knowledge and meager financial resources. All of these factors tend to create delays in vacating project areas and making them available for redevelopment. These factors also are an important local source of opposition to renewal projects. Congress has not included adequate business relocation as a required provision in loan and grant contracts, but it has aided displaced businesses by providing for federal grants to cover the full amount of local agency relocation payments to these businesses up to 2500 dollars for any one business enterprise. These federally financed payments are for moving expenses and actual direct losses of property except good will and profits. ${ }^{267} \mathrm{HHFA}$ also has advised the family relocation services of local public agencies to give what help they can to the relocating of businesses. ${ }^{268}$ Some have done so..$^{269}$

loss of profits during removal; In re Widening Third St. in St. Paul, 176 Minn. 389, 223 N.W. 458 (1929), no award for moving expenses. On eminent domain awards for incidental damages consult Orgel, Valuation Under Eminent Domain, c. 5 (2d ed., 1953); and Elements and Measure of Lessee's Compensation for Taking or Damaging Leasehold in Eminent Domain, 3 A.I.R.2d 286 (1949), annotating Karf v. Fleming, 239 Iowa 501, 32 N.W.2d 85 (1948).

${ }^{206}$ In the usual eminent domain case, all of the lessee's interest in the leased premises is taken. Under such circumstances, the lease is terminated by the taking, and the lessee is not obligated to pay rental for the period after the taking: Corrigan v. Chicago, 144 Ill. 537, 33 N.E. 746 (1893).

If the value of the leasehold at the time of taking is equal to or less than the remaining rent provided for in the lease, which is the usual situation when short-term leases are taken, the lessee is not entitled to an award for loss of his lease. State v. Platte Valley Pub. Power \& Irriga. Dist., 147 Neb. 289, 23 N.W. 2d 300 (1946); Newark v. Eisner, 100 N.J.Eq. 101, 135 Atl. 86 (1926). Also, many modern leases contain clauses under which the lessee waives his right to share in the award if the property is taken by eminent domain. 1 Amer. Law of Prop. $\$ 3.55$ (Casner ed., 1952). Examples of lease condemnation clauses are Am. Jur. Legal Forms Ann. $\$ \$ 5: 784,8: 55$, and 8:214 (1954).

${ }^{267}$ Note 251 supra. HHFA has defined actual direct losses of property as "With respect to such property as equipment, fixtures, machinery, supplies, and materials, the differences between (1) the fair market value for continued use at the present location, and (2) the fair market value delivered to another location. Does not include losses sustained as a result of property damaged during a move." 21 Fed. Reg. 9991 (1956), as amended 22 Fed. Reg. 1980 (1957).

268 "Although the relocation requirements of Title I are confined to the relocation of families, experience has indicated that offering all possible service to single persons and business establishments helps to create goodwill and expedite clearance of the area. This is particularly true in the case of small shops or stores which are gathering places in the area and the proprietor of which exercises substantial influence over the occupants. Also it is important to facilitate the removal of manufacturing or jobbing concerns and the demolition of commercial buildings since such activity emphasizes the determination of the Local Public agency to expedite the clearance of the site." HHFA, Local Public Agency Manual, Pt. 3, c. 4, \& 9 (1955).

260 "Full public acceptance of an overall development program requires proper relocation of displaced elements of the business community.

"To this end, the Redevelopment Agency staff includes a Business Relocation Officer who 


\section{Evaldation of the Federal Urban RenewaI Program}

The forces causing blight in American cities are far too fundamental and powerful to be controlled by the federal urban renewal program either in its present form or in the form it may take in the foreseeable future. But the program is a big step forward in government efforts to eliminate and prevent blight. Fundreds of substandard residential areas, many of them notorious slum pockets, are being wiped out and replaced by needed improvements. The program has created unprecedented interest in urban renewal and in city planning. Professional planning personnel has attained greater influence than ever before and is becoming a permanent part of local government. Widespread legislative support has been obtained for broadened renewal programs, with the courts generally recognizing that powers to carry out these programs may constitutionally be granted. A major success of the program has been the use of grant-in-aid conditions by the federal government to entice and enforce relatively high standards of urban renewal by local government. This is another illustration that federal wealth, channeled through the medium of grants-in-aid, can be used to eliminate from local government the lethargy, incompetency and dishonesty which so often characterize it. The grant-in-aid device is an invention of federalism that enables the advantages of a strong national government to influence problems that traditionally are matters of local and state jurisdiction.

Despite its successes, the urban renewal program has weaknesses. Housing for low-income families is not being substantially improved by the program, and in some cities is being worsened through eliminating low-income dwellings without providing for their replacement. Nor is new redevelopment project housing for upper and middle-income families filtering down to increase the low-income supply. Acute central city housing shortages for all income classes prevents this. It can be argued that substantial improvement in the low-income housing situation is not a major objective of the urban renewal program, and in some localities this is true, but Congress has repeatedly indicated a contrary intent. And if slum prevention has been divorced from the urban renewal program, this merely shifts responsibility for government failure in this area to another program or lack of one. A further weakness in the program is its great emphasis on land clearance projects compared with development of vacant land sites and rehabili-

\footnotetext{
is an experienced and qualified real estate agent familiar with the local market. This position is unique, so far as is known, among those agencies concerned with public improvements.

"His first function is to make a complete survey of businesses to be affected. The results of the survey showing space requirements of the various categories of businesses affected are then made available to the Real Estate Board and any interested real estate agents. After this preliminary work is completed, the Relocation Officer becomes a screen and catalyst working with businessmen to be displaced and the real estate agent or owner who has space available. He is aware of the needs and resources of the various businessmen, and he is aware, too, of the supply of space available in the market. He attempts to bring together the demand and supply, doing this in a way that does not interfere with the normal operation of the private real estate market." New Haven Workable Program 39 (1957).
} 
tation of existing structures. The cost of government writedown on these projects, totaling 150 million dollars a square mile ${ }^{270}$ means that the clearance device can be used to eliminate only a small proportion of urban blight. One effort that Congress has made to encourage blight prevention without emphasizing clearance is the workable program, stressing local planning and regulation. But the influence of the workable program has been minimized by the lenient way in which HHFA has administered it. Another point at which the federal urban renewal program is subject to criticism is in its concentration on problems and interests of central cities rather than on the problems and interests of metropolitan areas of which the central cities are merely a part. The special assistance program and a small number of suburban redevelopment projects have been minor departures from this over-riding concern with central city benefits. Many redevelopment projects have strengthened central cities relative to their suburbs, but the decisions to do so were not based on determinations of what the redeveloped areas, such as downtown commercial and shopping districts, would best be used for considering the needs and resources of the entire area. Concentration on central city problems has also meant that the urban renewal program has ignored the important and more cheaply dealt with problem of controlling the new development of newly urbanized outlying areas so as to prevent blight from eventually emerging there. ${ }^{271}$ Another possible weakness of the program concerns private redevelopers. It may be that the large redevelopers are being given more authority over projects than is desirable, that they have too great a voice in planning, and that their profits will be exorbitant. Perhaps better planning and better projects at a cheaper cost would result if HHFA and the local public agencies tried to attract more small redevelopers and did more of the planning on large projects.

Correcting the weaknesses in the federal urban renewal program will be difficult because, as with any major government effort, the conditions that have caused the weaknesses are deep-rooted and in large part based on strong political support. The short supply of decent low-income housing is a product of all the forces that have caused urban blight. Public housing, the best solution so far

${ }^{270}$ This includes both local government and federal government writedown contributions. Testimony of Thomas C. Downs, Jr., of Chicago, Hearings before Subcommittee of the Senate Committee on Banking and Currency on Housing Amendments of 1957, 85th Cong. 1st Sess. 923 (1957). Siegel and Brooks state that Chicago has twenty square miles of blight and near blight and fifty-six square miles of conservation areas; with two square miles of blight having been cleared at a cost of 150 million dollars a square mile. Siegel and Brooks, Slum Prevention Through Conservation and Rehabilitation II (1953). Chicago costs are somewhat higher than those in some middle-sized cities where real property is less valuable and where there is less density of building use.

271 Catherine Bauer has been particularly critical of the lack of government concern with the development and interests of the entire metropolitan area and the process of urban decentralization. Bauer, Redevelopment: A Misfit in the Fifties, in The Future of Cities and Urban Redevelopment 7 (Woodbury ed., 1953); Bauer, Housing, Planning and Public Policy, 17 Marriage and Family Living 101 (1955). 
worked out to improve the situation, is faced with opposition from influential business interests that are blocking all but token increases in the number of new units. The movement for large new public housing authorizations is weakened by the adverse criticism that even its proponents are making of the site location, design and administration of existing projects. A shift away from land clearance to rehabilitation is made difficult by the financial hardships on small home owners who are required to upgrade their premises, the tendency of rehabilitation to further reduce the short supply of housing, the weak popular appeal of rehabilitation compared to dramatic clearance projects, and by doubts as to the constitutionality of rehabilitation that imposes or enforces higher standards in one deteriorated area of a city than in other areas equally deteriorated. Also, rehabilitation involves less government financial support and this means that the federal government is not in as strong a position to insist on high standards of renewal performance as it is with costly clearance projects. Blight elimination and prevention on a metropolitan area basis is handicapped by the fragmented form of local government in metropolitan areas and the conflicts of interests among the various local municipalities, particularly central cities and their suburbs. Bearing on all of these issues is the opposition to federal intervention in local affairs. The balance of forces permitting the present degree of federal decision-making under the existing urban renewal program might be upset by efforts to increase federal control over the program.

Despite the opposition and risks involved, serious attempts should be made to modify the urban renewal program in these respects:

1. The federal government should continue to make substantial funds available for urban renewal, but as a condition to these grants it should exact more in the way of results from the localities. In particular, it should insist on greater workable program accomplishments, more attention to preventing future blight in outlying suburban areas, and a requirement that projects fit into a coordinated plan for the entire metropolitan area rather than one city in the area.

2. The low-income housing objectives of the urban renewal program should be reconsidered. If better low-income housing is to be a major objective of the program, it should be shaped to attain this goal. If low-income housing is merely an incidental concern of the program, the power and resources to do as much as the federal government can possibly do to solve this problem should be assigned to another program. The surest way to eliminate slums is to make enough decent housing available so that substandard dwelling units are driven off the market. Unsubsidized private enterprise cannot profitably build low-income housing. Large federal government subsidies are needed, and public housing is apparently the best and cheapest form of government subsidy for this purpose. More public housing should be built on vacant land so as to put less pressure on the housing supply; more of it should be in outlying areas where land costs are lower and low-density building is possible; and more of it should consist of rehabilitated housing which would eliminate substandard conditions, and if care- 
fully selected, reduce costs. Dispersal of public housing would help destroy minority-group concentrations in high density ghettos, a major cause of urban blight.

3. In new uses for urban redevelopment projects, more multi-family dwellings should be provided for middle-income families. Despite the abuses that occurred under Section 608, Congress and FHA should make further efforts to produce a substantial increase in the volume of new middle-income rental housing for large central cities. Where the shortage is critical, direct federal grants and loans should be considered for this type of project.

4. Even if improved housing conditions is a major goal of federal urban renewal, control of commercial and industrial blight should also be a goal. To enable better commercial and industrial renewal, Congress should free this type of blight control from the requirement that redevelopment project areas involve predominant or substantial residential uses. This requirement prevents redevelopment of many seriously blighted areas. The danger that removing the requirement would result in too much nonresidential renewal could be avoided by limiting the funds available for exclusively commercial or industrial projects.

5. The federal urban renewal program should increase its emphasis on rehabilitation in an effort to eliminate and prevent more blight with the money available. The rehabilitation provisions of the Housing Act of 1954 have had little success. Rehabilitation would be much easier if the low-income housing supply were eased because resistance to rehabilitation is strong when a critical shortage of low-income housing exists. A big incentive to more intense rehabilitation action by the localities would be to condition federal grants for clearance projects on local rehabilitation accomplishments. For example, the federal government could agree to pay the full write-down on a clearance project, but require as a condition to making the grant that the locality expend one-third as much in rehabilitating nearby areas. More projects should involve eminent domain takings of entire blighted areas, but with clearance of part of the area only, most of it to be sold for remodeling of existing structures for uses consistent with a redevelopment plan.

6. All federal agencies concerned with housing, urban renewal, or some other major form of urban land use should adhere to and implement a uniform blight control policy. In particular, FHA and the Veterans Administration should seek to prevent future urban blight in administering their insurance and guaranty programs, and the Federal Bureau of Public Roads should be required to adopt plans for new urban area highways and expressways that are consistent with general city plans designed to prevent and eliminate blight. Perhaps these agencies should be prohibited from acting in urban areas that do not have effective workable programs. Giving cabinet rank to an HHFA administrator with expanded jurisdiction would help; but even with existing rank and jurisdiction, federal blight control efforts could be made more effective by better policy coordination among the constituent agencies and units of HHFA. 
7. More provision should be made for research, and research should be accepted as an important function of HHFA. The need is not filled by the demonstration grant program. More data is required on the nature of commercial blight and plans for combating it; better studies are needed on the shortcomings of existing public housing and means of correcting them; more should be known about the role of private redevelopers; and the effect of urban redevelopment projects on blight prevention should be carefully observed. Data on redevelopers might best be acquired by congressional inquiry. HHFA should also be giving greater research study to improving its procedures and personnel allocations so as to reduce delays in processing project approvals and to eliminate unnecessary local public agency paper work.

The future of the federal urban renewal program is doubtful. It has not achieved acceptance as a permanent grant-in-aid program. Government economy forces will try to abolish it, and one means of doing so may be by seeking Congressional acceptance of it as one of several grant-in-aid programs to be turned back to the states, ostensibly to be paid for with a release of some federal tax sources. Whether this attempt is made or not, with an increasing number of cities asking for loan and grant funds, Congress may reduce the proportion of federal aid available for clearance projects and increase its assistance to local rehabilitation efforts. Even if the present program is abolished entirely, rising pressure on the federal government to assist cities with their blight and housing problems can be expected. Increased urbanization will make these problems more acute, and the federal government will be the only institution available with enough resources to relieve the cities. 